\title{
2. REGIONAL OCEANOGRAPHIC SETTING OF THE SOUTHWESTERN ATLANTIC 1
}

\author{
David A. Johnson, Woods Hole Oceanographic Institution, Woods Hole, Massachusetts
}

\begin{abstract}
Several major water masses converge in the southwestern Atlantic, and, therefore, the region is a suitable target area for a number of important paleoceanographic drilling objectives. The flanks of the Rio Grande Rise intersect several water masses: Antarctic Intermediate Water (AAIW), 900-1000 m; Upper Circumpolar Water (UCPW), 1300-1550 m; North Atlantic Deep Water (NADW), 2300-3200 m; and Antarctic Bottom Water (AABW), below 4000 m. During DSDP Leg 72, the pelagic sediments draping the Rise and those in the deeper Vema Channel and Brazil Basin were the focus of several drilling objectives, including: (1) determine the time of onset of AABW flow through the Vema Channel; (2) establish the time of the initial production of a northern source of bottom water; (3) examine the effects of major episodes of ice growth in polar regions upon the production and strength of deep thermohaline currents; (4) investigate the effects of major tectonic reconfigurations upon the thermohaline circulation; and (5) analyze cores obtained by the hydraulic piston corer (HPC) to obtain time-series observations of geologic "fingerprints" of paleocirculation, and, by use of these records, achieve a better understanding of the teleconnective linkages between the major water masses.
\end{abstract}

\section{INTRODUCTION}

DSDP Leg 72 of the Glomar Challenger addressed paleoceanographic objectives in the southwestern Atlantic by use of the new technology of hydraulic piston coring (HPC) developed by DSDP engineers. The sites drilled during Leg 39 had been generally only spot-cored because of time limitations (Perch-Nielsen, Supko, et al., 1977), and as a result many key questions pertaining to the oceanographic development of the Cenozoic South Atlantic remained unanswered. We hoped to extend the observations and interpretations from the Leg 39 report in the following principal respects:

1) Obtain a complete deposition record of pelagic sedimentation on the Rio Grande Rise, down to and including the underlying volcanic basement.

2) Perform hydraulic piston coring in the Neogene intervals at several sites on the flanks of the Rise, in the anticipation that high core recovery and a lack of core disturbance would enable us to make several time-series observations of key geologic indicators of paleocirculation.

3) Core continuously down to and through a major seismic discontinuity in the Brazil Basin, a reflector that has been correlated to the Reflector A complex in the Vema Channel and that presumably marks the onset of strong northward advection of thermohaline bottom currents (Gamboa et al., this volume). The sediments above this reflector complex would presumably contain a record of major pulses of Antarctic Bottom Water (AABW) flow since its initiation.

Some of the above paleoceanographic objectives were achieved satisfactorily on $\operatorname{Leg} 72$, and others will require subsequent drilling. Our experience from Leg 72 reinforces the often-repeated wisdom that it is far preferable to core continuously and complete a given site rather

\footnotetext{
${ }^{1}$ Barker, P. F., Carlson, R. L., Johnson, D. A., et al., Init. Repts. DSDP, 72: Washington (U.S. Govt. Printing Office).
}

than to compromise one's objective by simply spot-coring so that one can adhere to an arbitrary timetable and proceed to other proposed drill sites. DSDP has a long history of re-occupying previously drilled locations. We re-emphasize to our colleagues that our experience on Leg 72 has shown the value of persistence in completing a particular site, as long as conditions are favorable for continuation of drilling.

In this report I shall review the major physiographic, oceanographic, and sedimentologic characteristics of the regions that were targets for paleoceanographic drilling on Leg 72. Barker and Carlson (this volume) summarize the geophysical, volcanic, and tectonic setting of the region. Additional details on the geophysical framework of the southwestern Atlantic include papers by Sclater et al. (1977), Detrick et al. (1977), Rabinowitz and LaBrecque (1979), and Kumar (1979).

\section{REGIONAL PHYSIOGRAPHY}

The regional physiographic features of the southwestern Atlantic (Fig. 1) are crucial in providing boundary conditions for controlling modern circulation patterns. It is clear that the continuing readjustments of these topographic boundaries during the evolution of the South Atlantic must be taken into account in explaining major paleocirculation events during the Cretaceous and Tertiary. In this section I shall review the major physiographic controls on thermohaline circulation in the southwestern Atlantic today.

\section{Rio Grande Rise}

This aseismic rise extends upward to several flattopped banks with a minimal depth of $\sim 650 \mathrm{~m}$, superimposed on a regional summit with a minimum depth of $\sim 1300 \mathrm{~m}$ (Figs. 2-3). The banks clearly reflect the volcanic nature of the basement beneath the Rise (Fodor et al., 1977), and contain fossil material of shallow-water origin (Thiede, 1977). The north flank of the Rise is steeply sloping and heavily dissected by erosional canyons (Johnson and Peters, 1979). The south and west 


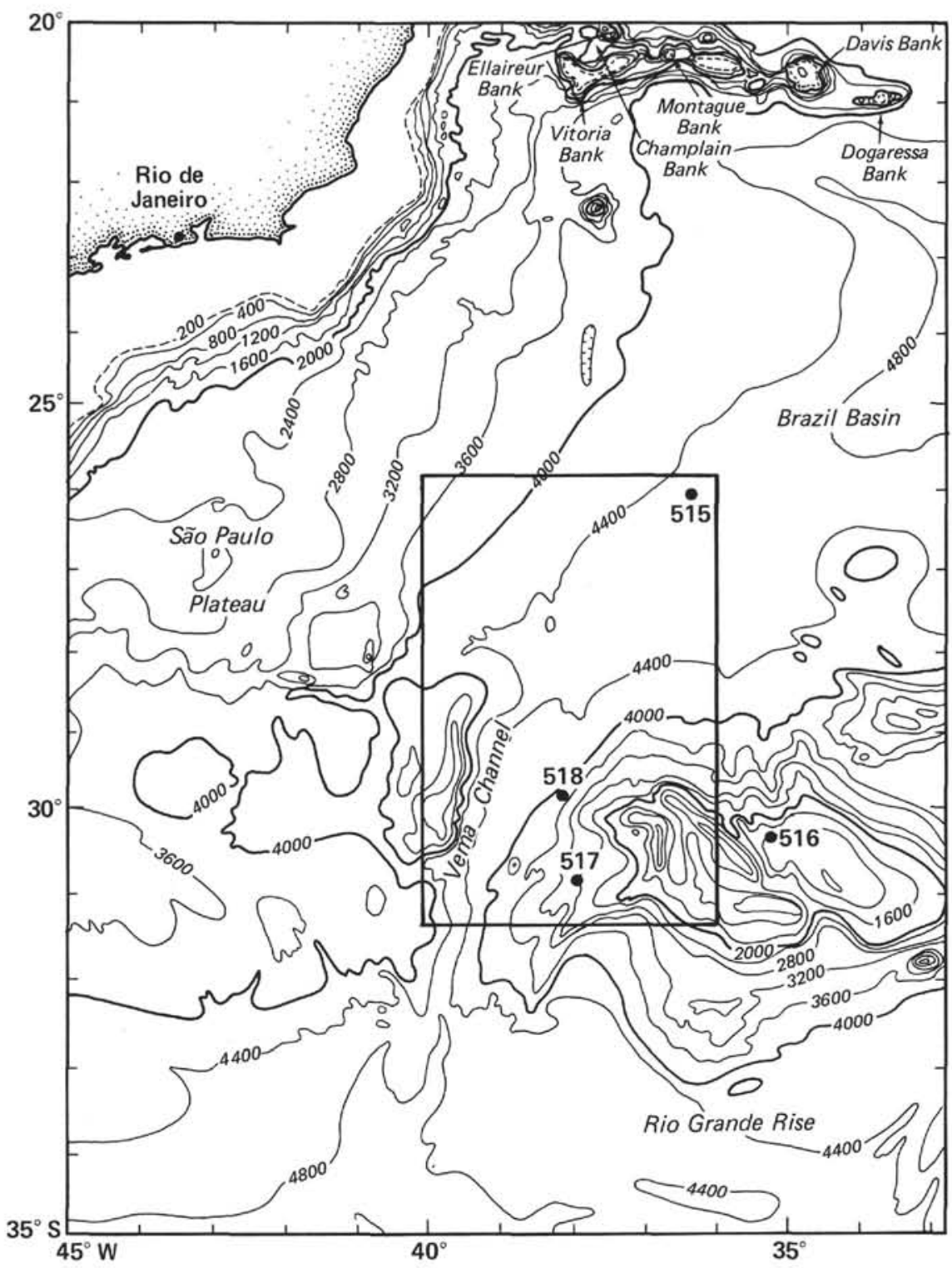

Figure 1. Index map of the southwestern Atlantic, showing the principal basins and topographic elevations. The box outlines the Vema Channel and western Rio Grande Rise regions, shown in detail on Figure 2. Leg 72 DSDP sites are shown.

flanks, however, are gently sloping and show no evidence for massive downslope reworking. Pelagic sediments on these flanks generally show thick, conformable sub-bottom stratification (Fig. 4). The Rise intersects several major water masses of the southwestern Atlantic, and consequently the sediments draping the Rise can be interpreted in terms of the history of these water masses. The Rise may exert some influence on the southward penetration of North Atlantic Deep Water (NADW), although NADW clearly is able to pass southward through the Vema Channel (Hogg et al., 1982). The principal oceanographic effect of the rise is to restrict the northward flow of AABW.

\section{Vema Channel}

This passage, with a sill depth of $\sim 4550 \mathrm{~m}$ near $31^{\circ} \mathrm{S}$ (Fig. 2), allows a significant fraction of AABW (2-6 $\times$
$10^{6} \mathrm{~m}^{3} / \mathrm{s}$; see Hogg et al., 1982) to enter the Brazil Basin. The channel is asymmetric in cross-section (Figs. 5-7), with evidence for the presence of a buried paleochannel at some locations (Gamboa et al., this volume). The channel is characterized by a broad terrace on the eastern flank, with a remarkably uniform mean depth ranging from $4050 \mathrm{~m}$ in the south to $4200 \mathrm{~m}$ at the northern channel exit (Fig. 2). The terrace is capped by a series of regular abyssal sediment waves, with amplitudes of $50-150 \mathrm{~m}$ and wave lengths of $1-3 \mathrm{~km}$. Similar features are characteristic of fine-grained pelagic sediments in regions of persistent thermohaline current flow (Flood, 1980). The channel geometry and flow characteristics within the channel are inextricably related (Hogg et al., 1982). In particular, the water properties and flow patterns show significant cross-channel asymmetry, and consequently one cannot necessarily extrapolate across 


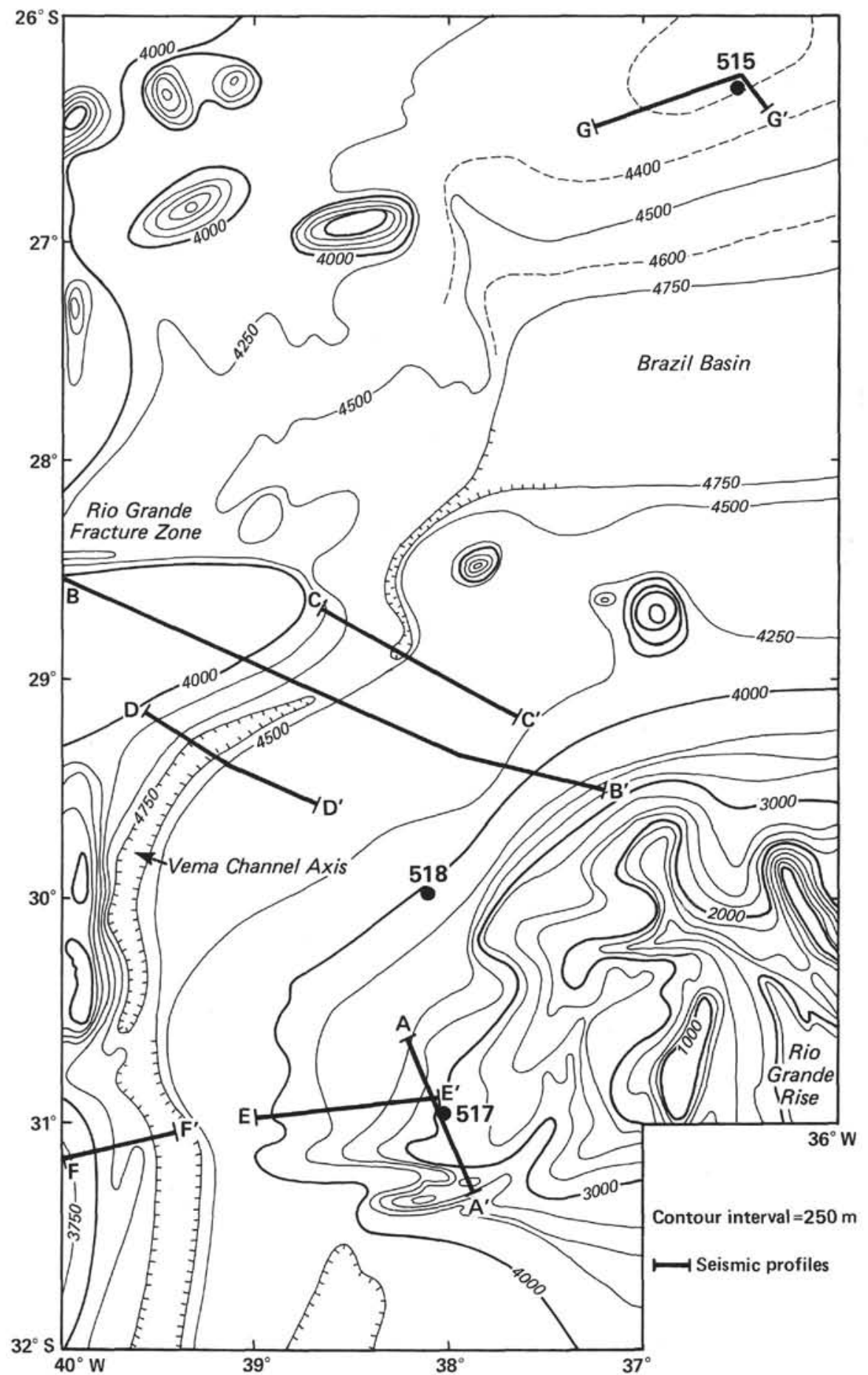

Figure 2. Bathymetry of the Vema Channel, western Rio Grande Rise, and southwestern Brazil Basin, modified after Moody et al. (1979). Additional topographic control based on recent cruises (Atlantis II, 107; Fred Moore, 105-106; Glomar Challenger, 71-72). Locations of all DSDP sites in the region are shown. Labeled ship tracks denote seismic reflection profiles illustrated in subsequent figures of this paper.

channel to infer near-bottom water characteristics on the opposite side.

\section{Brazil Basin and Argentine Basin}

Each of these basins has sill regions at its northern and southern perimeters that govern and limit the flow of bottom water. The flow of AABW into the Argentine Basin is governed by the topographic complexities in the Scotia Arc and Falkland Fracture Zone complex (Georgi, 1981). At the northern margin of the Argentine Basin, the Vema Channel allows a major fraction (perhaps 10$25 \%$ ) of AABW to enter the Brazil Basin, with the re- 


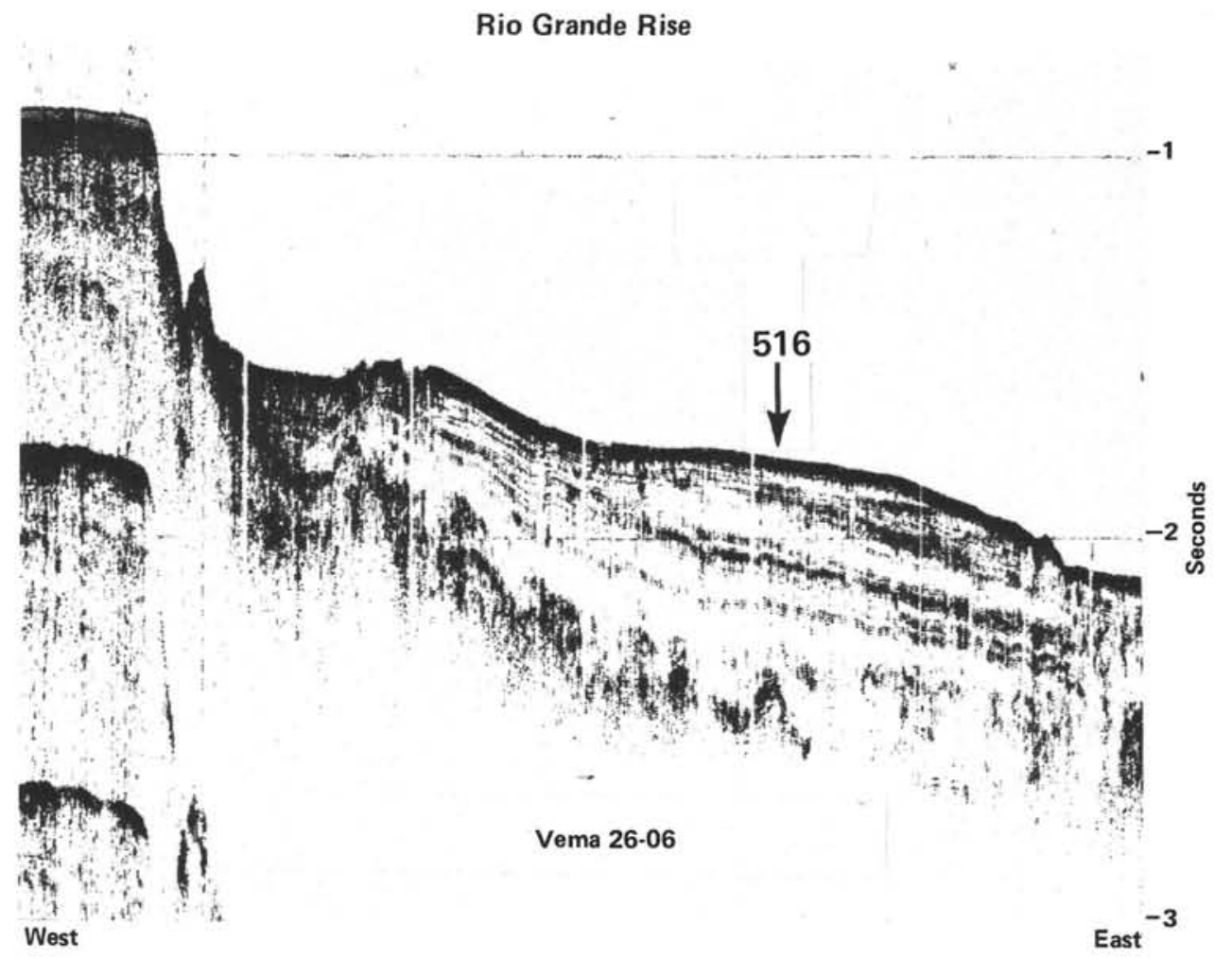

Figure 3. Pelagic sediments capping the upper flanks of the Rio Grande Rise in the vicinity of Site 516. The summit is marked by several shallow $(<1200 \mathrm{~m})$ flat-topped banks, shown at the left of this profile and elsewhere on Figure 2. These banks are of volcanic origin (Fodor et al., 1977) and probably reflect a major episode of vulcanism during the middle Eocene (Bryan and Duncan, this volume).

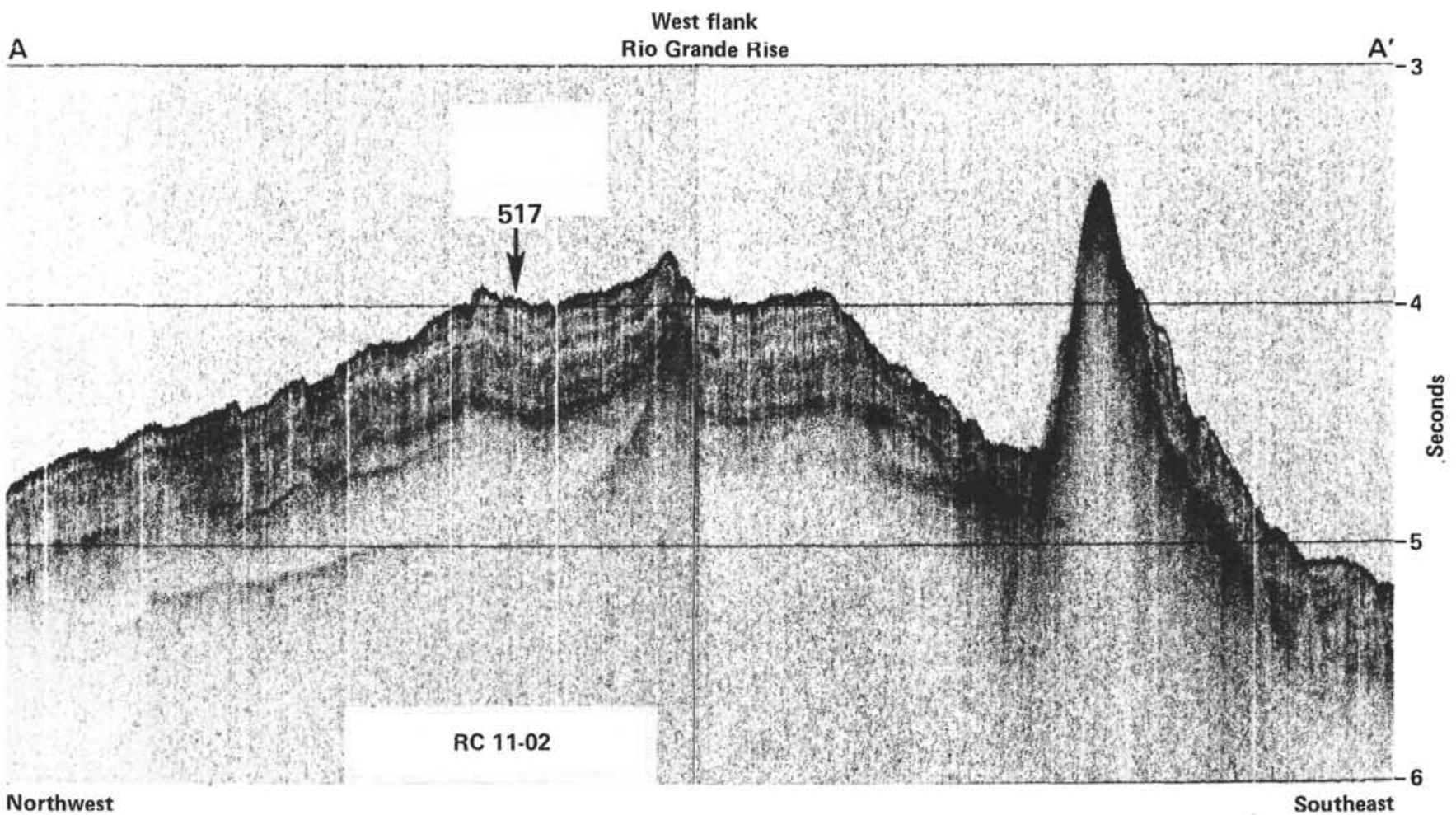

Figure 4. Draping pelagic sediments on the west flank of the Rio Grande Rise near Site 517. The west and south flanks of the Rise are gently sloping with relatively little sediment deposition. The north flank by contrast, is dissected by deep erosional canyons (McDowell et al., 1977; Johnson and Peters, 1979). A and $\mathrm{A}^{\prime}$ refer to locations marked on Figure 2. 


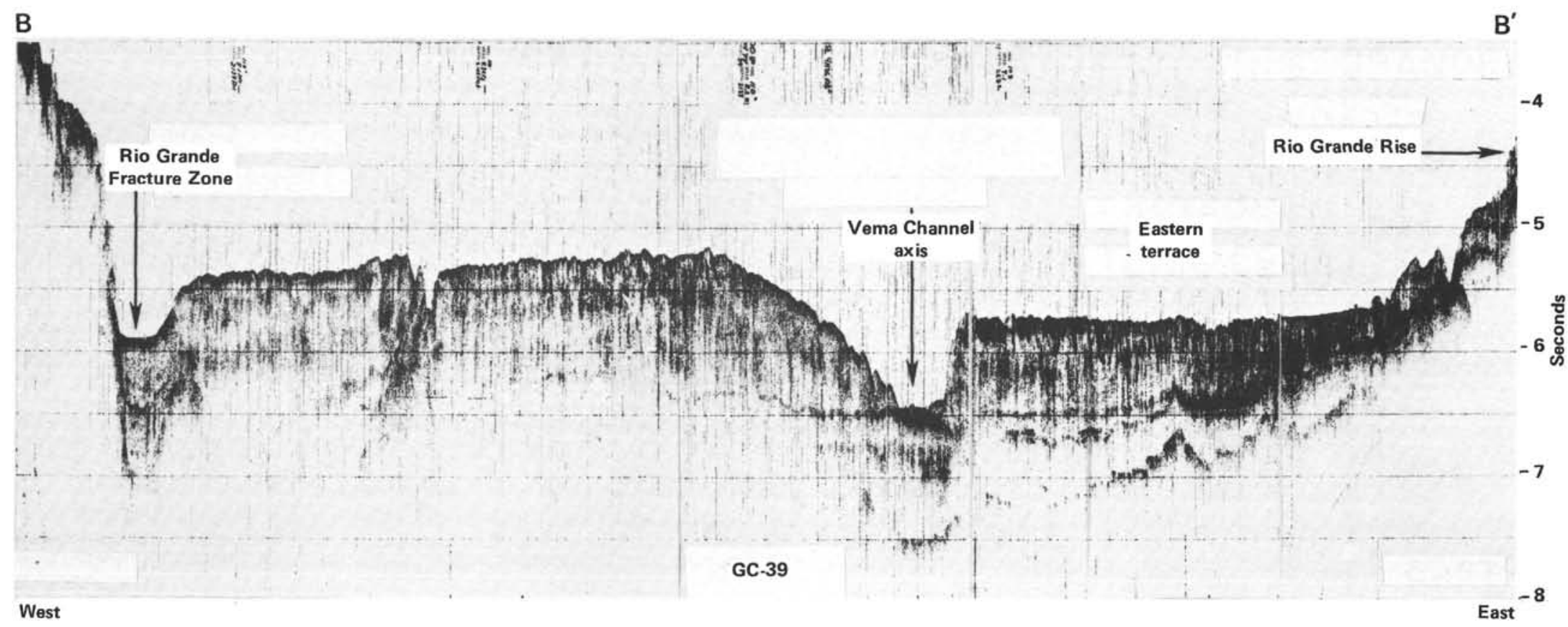

Figure 5. Seismic profile across western branch and main axis of Vema Channel near $29^{\circ} \mathrm{S}$. Strong northward flow of AABW is confined below a depth of $\sim 5.4 \mathrm{~s}(\sim 4000 \mathrm{~m})$. B and $B^{\prime}$ refer to locations marked on Figure 2. 

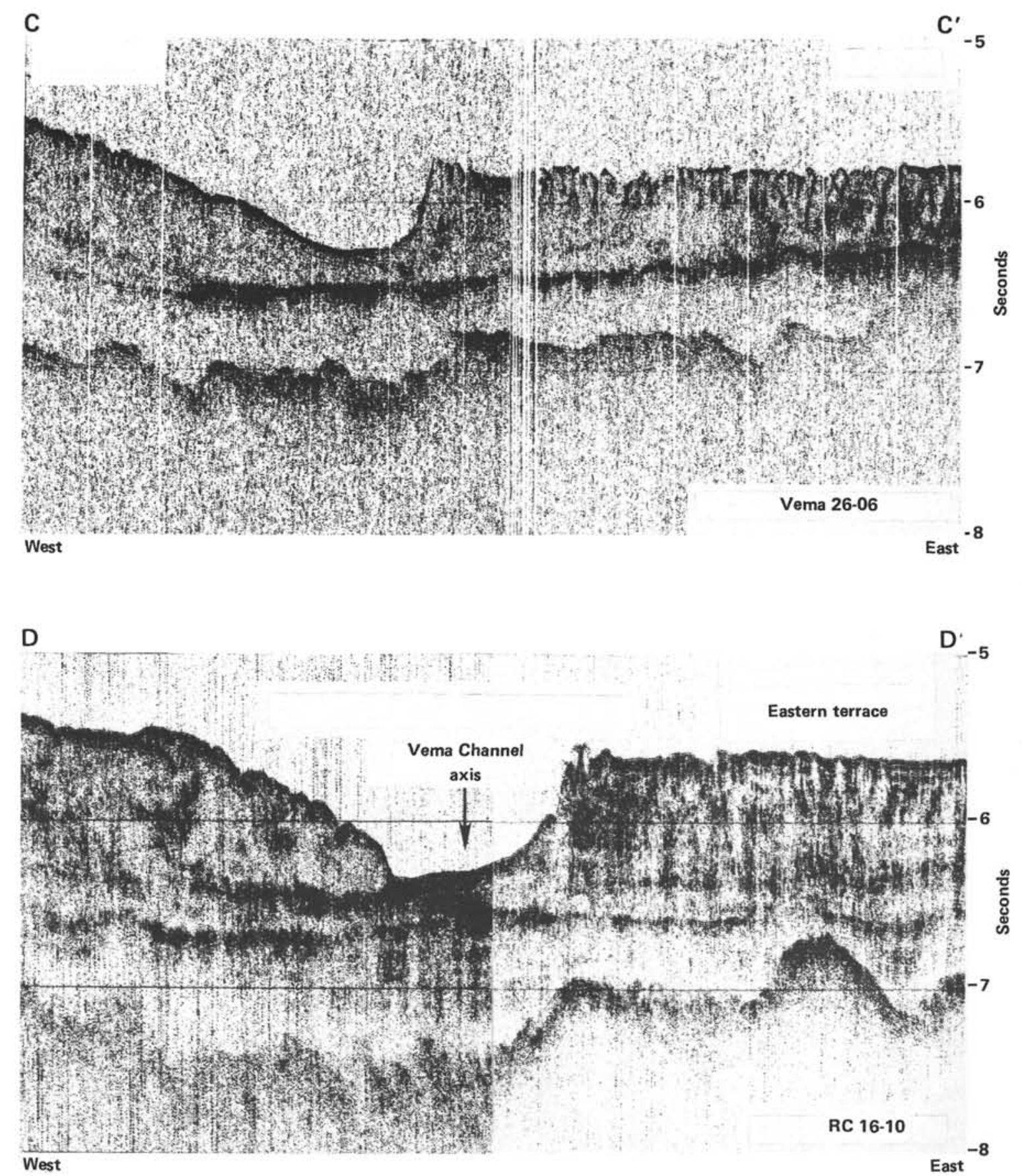

Figure 6. Seismic profiles of Vema Channel axis and eastern terrace near $30^{\circ} \mathrm{S}\left(\mathrm{C}, \mathrm{C}^{\prime}, \mathrm{D}\right.$, and $\mathrm{D}^{\prime}$, refer to locations on Fig. 2). The strong acoustic reflector at $\sim 6.5 \mathrm{~s}$ is an erosional surface denoting the intiation of northward flowing AABW during the Paleogene (Gamboa et al., this volume).

mainder of AABW continuing in a cyclonic gyre in the interior of the Argentine Basin. The sediment distribution pattern in the Vema Channel and in the southern Brazil Basin reflects the erosion and redeposition of sediments entrained in northward-flowing AABW. Sediment is notably thinned in the Vema Channel axis and thickened at the northern channel exit (Fig. 8). The anomalous thickness of sediments in the southern Brazil Basin was one of the principal targets for drilling on Leg
72 (Fig. 9). There is no evidence that a deep enough channel exists between the Rio Grande Rise and the western flanks of the Mid-Atlantic Ridge to allow AABW to enter the Brazil Basin via an eastern route. However, this region (the Hunter Channel) is relatively unsurveyed, and the possibility remains that a second conduit for AABW may be found. The northern Brazil Basin funnels to a sill region near $04^{\circ} \mathrm{N}$ (Whitehead and Worthington, 1982). This sill may serve to intensity AABW 
A

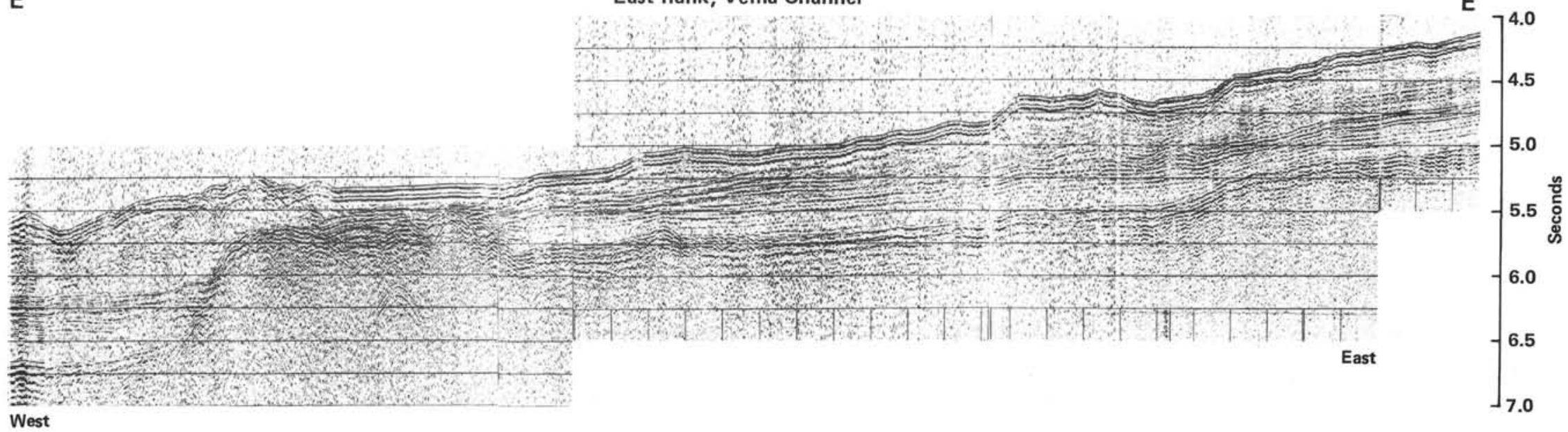

\section{B}

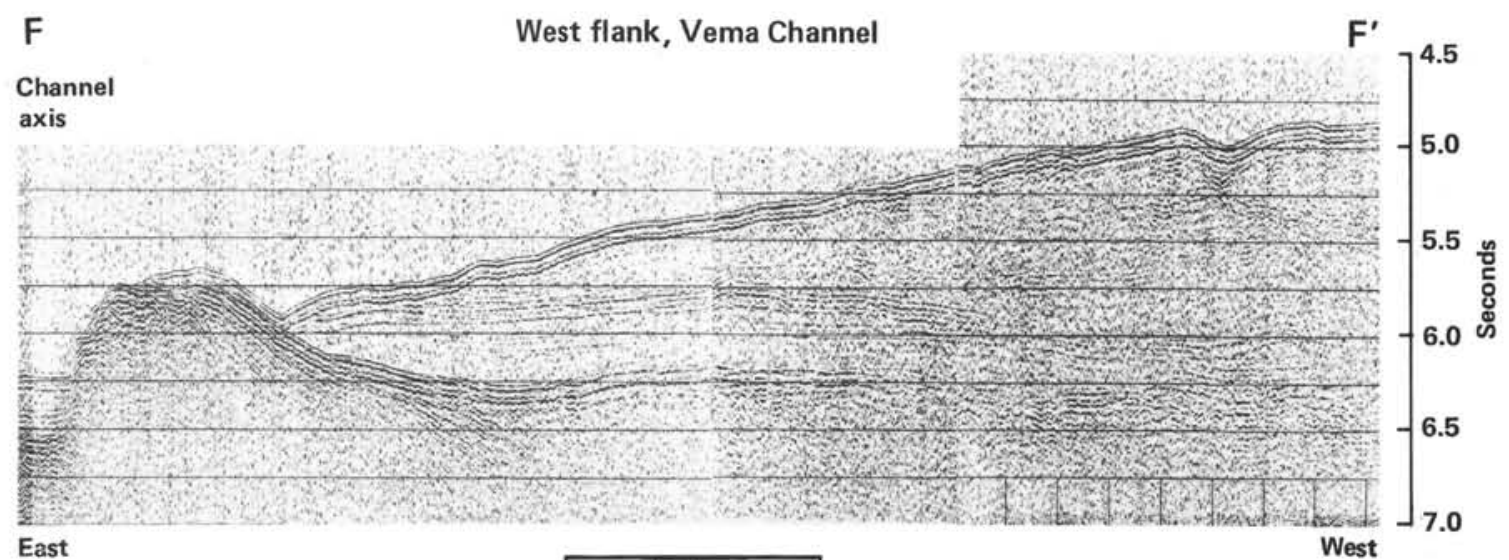

$10 \mathrm{~km}$

Figure 7. Seismic profile across Vema Channel near $31^{\circ} \mathrm{S}\left(\mathrm{E}, \mathrm{E}^{\prime}, \mathrm{F}\right.$, and $\mathrm{F}^{\prime}$ refer to profile locations on Fig. 2). Profile shows differential sediment accumulation around basement elevations and considerable lateral thickening or thinning of sub-bottom strata below $4.5 \mathrm{~s}(\sim 3400 \mathrm{~m})$. This is in marked contrast to the uniform deposition pattern at shallower depths (Fig. 4), and suggests that strong bottom current activity has characterized this region for several million years. 


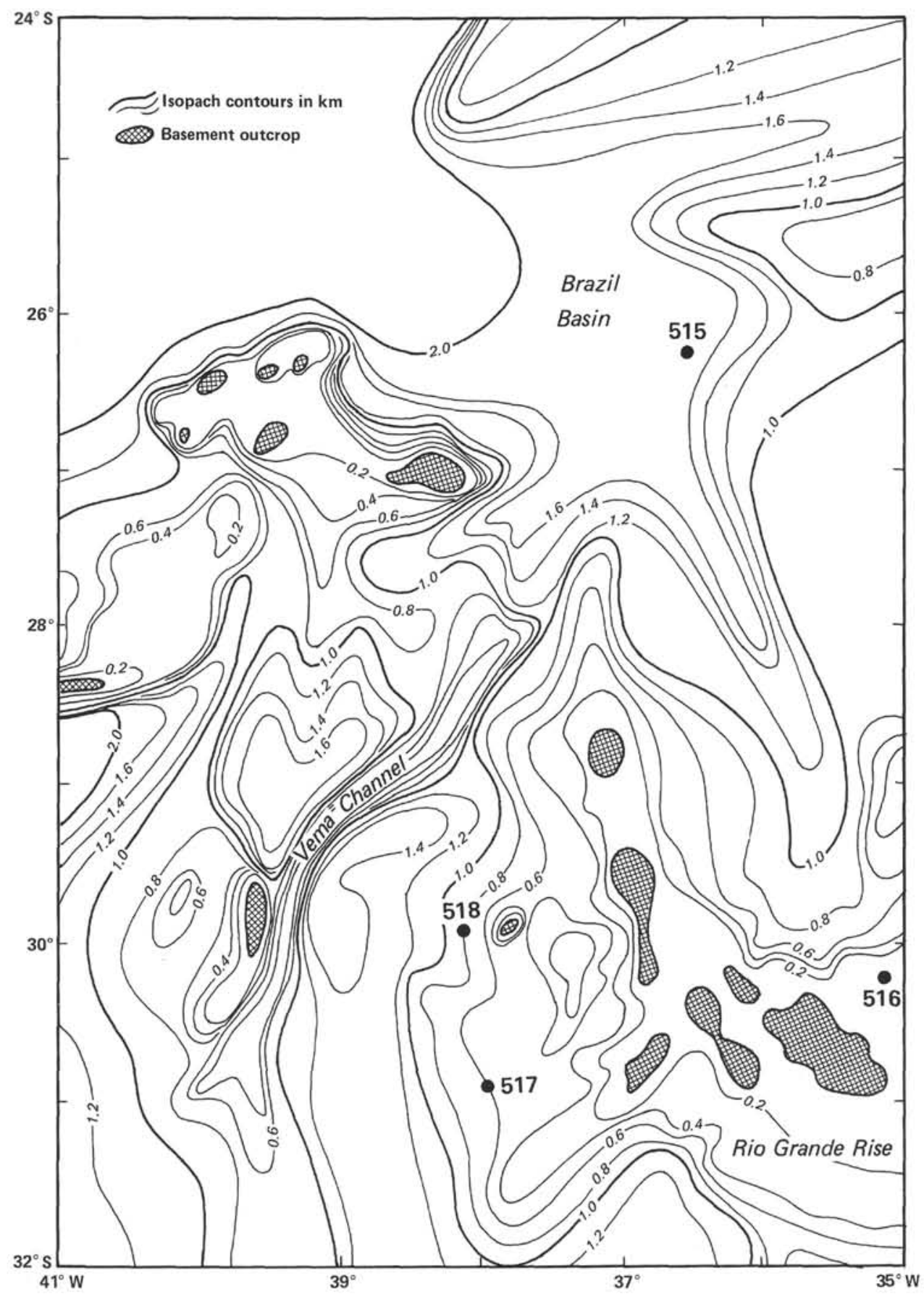

Figure 8. Isopachs of the southern Brazil Basin, modified after Kumar et al. (1979). Note the wedge of anomalously thick sediments in the region near Site 515 . The anomalous thickness may be a consequence of sediment advection by AABW and redeposition north of the Channel exit. Alternatively, some of the sediment components may have their source at the canyon exit on the north flank of the Rio Grande Rise near $35^{\circ} 30^{\prime} \mathrm{W}$.

flow locally, but does not appear to form a significant barrier to modern-day flow of AABW into the North Atlantic.

\section{HYDROGRAPHY AND CIRCULATION PATTERNS}

The oceanography of the southwestern Atlantic has been the subject of numerous major research programs during the past decade. Studies of a regional nature include the GEOSECS program (e.g., Broecker et al., 1976; Broecker and Takahashi, 1980; Bainbridge, 1980) and the hydrographic and current meter observations of Reid et al. (1977). Observations focused more specifically on circulation through the Vema Channel include the data reported by LePichon et al. (1971), Johnson et al. (1976), and Hogg et al. (1982).

\section{Principal Water Masses}

In this report, we will focus only upon the water properties below the main thermocline, since this is the depth interval of greatest interest for paleoceanographic inter- 


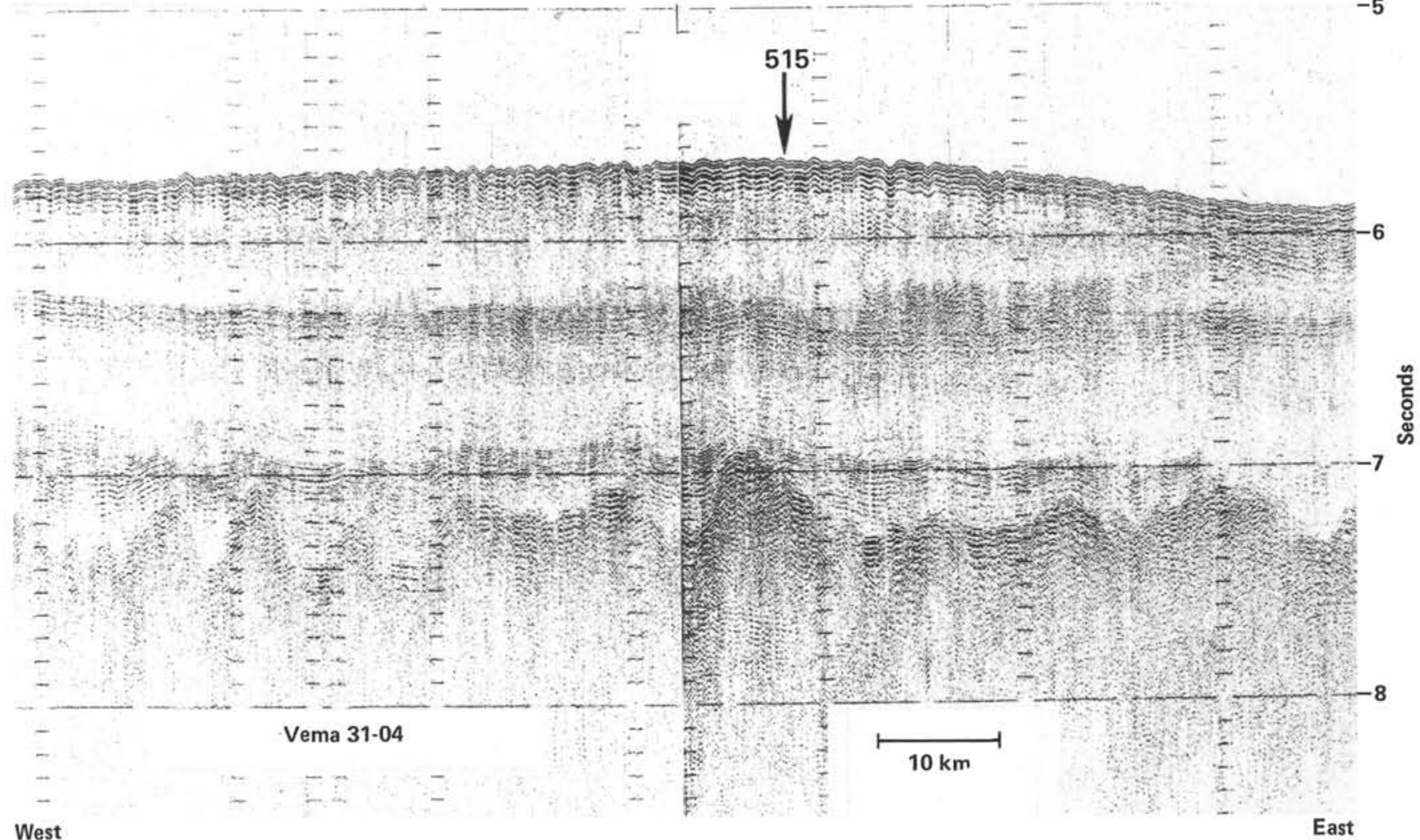

Figure 9. Seismic profile near Site 515 in the southwestern Brazil Basin, showing the anomalous thickening of strata above a regional acoustic reflector at $\sim 6.3 \mathrm{~s}$. G and $\mathrm{G}^{\prime}$ refer to profile locations on Figure 2.

pretations of the geologic record. Let us consider a vertical profile of water properties near $30^{\circ} \mathrm{S}$ in the southwestern Atlantic (e.g., GEOSECS Station 59 in the Vema Channel axis; see Bainbridge, 1980). Using the standard properties of salinity, potential temperature, and dissolved oxygen, one can conveniently divide the water column into several water masses (Table 1; Fig. 10). For reasons discussed later in this paper, it is preferable to consider these water masses not in terms of having clearly defined boundaries, but rather as "core" layers bordered

Table 1. Principal water masses near $30^{\circ} \mathrm{S}$ in the southwestern Atlantic below the main thermocline, modified after Reid et al. (1977) and Bainbridge (1980).

\begin{tabular}{|c|c|c|c|}
\hline Water mass & & $\begin{array}{l}\text { Depth of } \\
\text { "core" region (m) }\end{array}$ & Diagnostic properties \\
\hline $\begin{array}{l}\text { Antarctic Intermediate } \\
\text { Water }\end{array}$ & & $900-1000$ & $\begin{array}{l}\text { Low salinity } \\
\qquad(\mathrm{S}<34.28 \%)\end{array}$ \\
\hline $\begin{array}{l}\text { Upper Circumpolar } \\
\text { Water }\end{array}$ & & $1300-1550$ & $\begin{array}{l}\text { Low oxygen } \\
\qquad\left(\mathrm{O}_{2}<195 \mu \mathrm{M} / \mathrm{kg}\right)\end{array}$ \\
\hline $\begin{array}{l}\text { North Atlantic Deep } \\
\text { Water }\end{array}$ & & $2300-3200$ & $\begin{array}{l}\text { High salinity } \\
\quad(\mathrm{S}>34.90 \%) \\
\text { High oxygen } \\
\quad\left(\mathrm{O}_{2}>250 \mu \mathrm{M} / \mathrm{kg}\right)\end{array}$ \\
\hline $\begin{array}{l}\text { Lower Circumpolar } \\
\text { Water }\end{array}$ & $\begin{array}{l}\text { Antarctic } \\
\text { Bottom }\end{array}$ & $4000-4200$ & $\begin{array}{l}\text { Weak oxygen minimum } \\
\qquad\left(\mathrm{O}_{2}<224 \mu \mathrm{M} / \mathrm{kg}\right)\end{array}$ \\
\hline $\begin{array}{l}\text { Weddell Sea } \\
\text { Deep Water }\end{array}$ & $\begin{array}{l}\text { Bottom } \\
\text { Water }\end{array}$ & $<4200$ & $\begin{array}{l}\text { Low potential temperature } \\
\qquad\left(\theta<\mathrm{O}^{\circ} \mathrm{C}\right)\end{array}$ \\
\hline
\end{tabular}

Note: In this paper we have retained the familiar designation "Antarctic Bottom Water" for the entire region below $-4000 \mathrm{~m}$ in the Vema Channel region. Strictly speaking, one could subdivide this flow into a circumpolar component and a component of Weddell Sea origin (Reid et al., 1977). However, since this distinction is not reflected in the geologic record, we have elected to use the AABW terminology. by relatively thick (up to several hundred meters) transition zones between "adjacent" water masses. In the following paragraphs, the principal water masses near $30^{\circ} \mathrm{S}$ are described, in order from shallowest to deepest.

\section{Antarctic Intermediate Water (AAIW)}

The relatively fresh surface water that encircles the Antarctic continent has a northward component due to the Coriolis deflection. This water sinks at the Polar Front, or Antarctic Convergence (Gordon, 1971), and continues northward as a shallow subsurface tongue of low-salinity water, centered at a depth of 900-1000 m (Buscaglia, 1971; Bainbridge, 1980). This tongue can be traced as far north as $\sim 25^{\circ} \mathrm{N}$, where it becomes indistinguishable because of the influx of hypersaline Mediterranean water (Worthington, 1976). The summit of the Rio Grande Rise lies within AAIW, and consequently the pelagic sediments on the crest of the Rise offer a unique opportunity to decipher the history of AAIW fluctuations.

\section{Upper Circumpolar Water (UCPW)}

A strong oxygen minimum near $1400 \mathrm{~m}$ (Fig. 10; Table 1) denotes the presence of an upper branch of Circumpolar Water. This water mass is markedly depleted in oxygen because, as it encircles Antarctica, it is out of contact with the atmosphere for prolonged periods. Circumpolar Water has density comparable to that of NADW flowing south, and as a result, NADW splits 


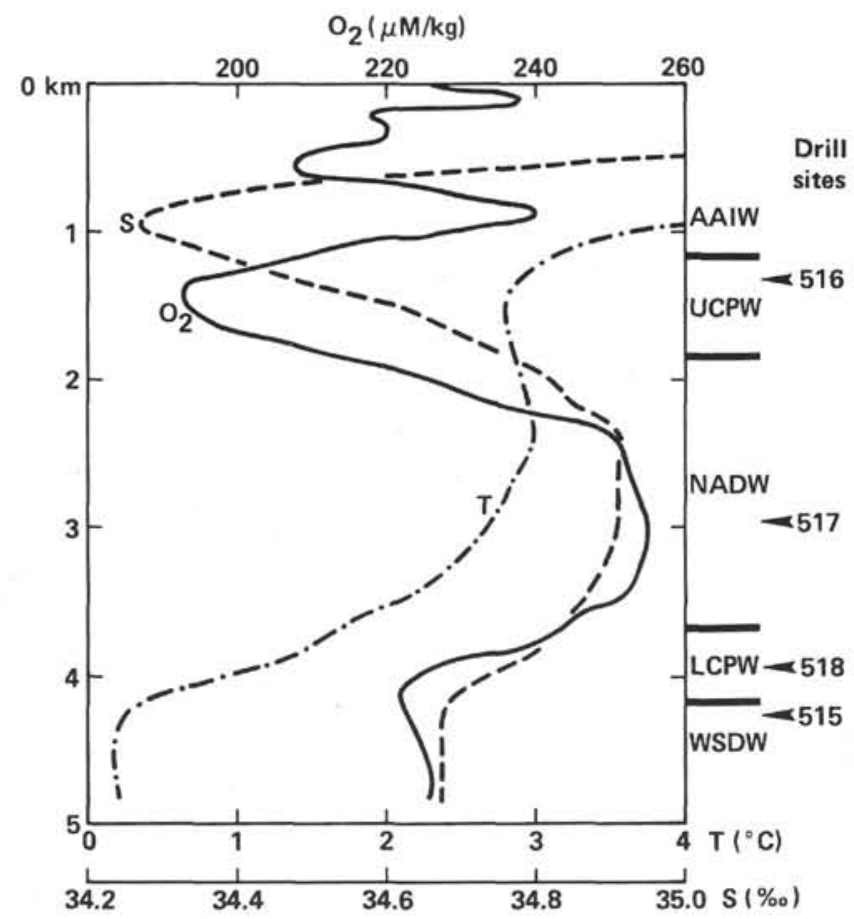

Figure 10. Summary of principal water masses in the southwestern Atlantic, modified after Reid et al. (1977). Positions of Leg 72 drill sites are shown in relation to these water masses. See text for discussion of diagnostic properties of each water mass. AAIW = Antarctic Intermediate Water; UCPW $=$ Upper Circumpolar Water; NADW $=$ North Atlantic Deep Water; LCPW $=$ Lower Circumpolar Water; WSDW $=$ Weddell Sea Deep Water; $\mathrm{T}=$ temperature.

CPW into an upper and a lower branch (Reid et al., 1977, p. 72). One might expect that the sharpness of this oxygen minimum would be reflected in the degree of preservation of calcareous microfossils in the underlying sediments.

\section{North Atlantic Deep Water (NADW)}

The northern North Atlantic is the source region for this southward-flowing tongue of water of high salinity and high oxygen (Broecker, 1979; Broecker and Takahashi, 1980). Wüst (1936), in his original description of NADW, divided the water mass into three layers on the basis of dissimilarities between the oxygen and salinity profiles at mid-depths (Fig. 10). Even though the oxygen and salinity maxima associated with NADW do not correspond exactly in depth, this distinction is probably not resolvable in the geologic record, and therefore we shall treat the entire depth interval from 2300 to $3200 \mathrm{~m}$ as representing the "core" of NADW (Table 1; Fig. 10).

\section{Antarctic Bottom Water (AABW)}

A transition zone nearly $1 \mathrm{~km}$ in thickness underlies the "core" region of NADW, denoting the downward transition into waters of southern origin. For convenience, I have elected to retain the familiar designation "Antarctic Bottom Water" for the low-salinity, lowtemperature, high-silica waters of southern origin below approximately $4000 \mathrm{~m}$ (Table 1 ). Strictly speaking, however, one could divide the waters below $4000 \mathrm{~m}$ into an upper layer of circumpolar origin, denoted by a weak oxygen minimum, and a lower layer of Weddell Sea origin (Reid et al., 1977).

\section{Flow Patterns}

Three basic approaches are used by physical oceanographers to interpret the flow field within a particular ocean region. Each of these methods alone is not entirely satisfactory as a complete description of the flow, either because of assumptions required in applying the method or because of the spatial and temporal scales over which the observations are integrated. These approaches may be classified as one of the following types: (1) direct measurement of the flow, either via instruments attached to "fixed" moorings or via neutrally buoyant "Swallow floats" that can be tracked from surface vessels; (2) dynamic computations, applying the geostrophic relationship to the density field measured in a transect of hydrographic stations and using an assumed "reference level" where the velocity is known or can be assumed (e.g., Warren, 1981) or (3) inverse methods, in which one requires conservation of particular water properties within a region of suitable dimensions (e.g., Wunsch, 1978). The above approaches are all quantitative. Other approaches, such as isopycnal analysis (e.g., Reid and Lynn, 1971), give excellent representations of the sense of flow integrated over lateral dimensions of thousands of kilometers. In this method, one can follow a diagnostic water property along an appropriate surface of constant potential density to obtain a qualitative sense of the direction of advection of particular water masses. This method, however, is not quantitative in specifying either the local flow field or integrated volume transport.

I have listed in Table 2 some of the principal studies of flow dynamics in the subtropical southwestern Atlantic, as well as studies focused more specifically upon the flow within the Vema Channel. I shall summarize the major interpretations that have emerged, particularly those that provide a regional oceanographic framework for DSDP Leg 72 drilling objectives.

1) The pronounced tongue of low-salinity AAIW near $1000 \mathrm{~m}$ strongly suggests northward flow at these

Table 2. Physical oceanographic interpretations of flow dynamics in the southwestern Atlantic, indicating the principal approaches of each study.

\begin{tabular}{|c|c|}
\hline $\begin{array}{l}\text { Regional studies of } \\
\text { flow in subtropical } \\
\text { southwestern Atlantic }\end{array}$ & $\begin{array}{l}\text { Observational and } \\
\text { interpretive approaches }\end{array}$ \\
\hline Wüst, 1936 & Hydrographic stations $^{\mathrm{a}}$ \\
\hline Metcalf, 1960 & Hydrographic stations \\
\hline Wright, 1969; 1970 & Hydrographic stations \\
\hline Buscaglia, 1971 & Isopycnal analysis \\
\hline Broecker et al., 1976; 1980 & Hydrographic stations \\
\hline Reid et al., 1977 & Hydrographic stations, moored current meters \\
\hline Georgi, 1981 & Hydrographic stations \\
\hline Fu, 1981 & Inverse methods \\
\hline Whitehead and Worthington, 1982 & Hydrographic stations, moored current meters \\
\hline \multicolumn{2}{|l|}{ Vema Channel flow } \\
\hline Le Pichon et al., 1971 & Thermograd on piston core \\
\hline Johnson et al., 1976 & Hydrographic stations, moored current meters \\
\hline Hogg et al., 1982 & Hydrographic stations, moored current meters \\
\hline
\end{tabular}


depths. In addition, isopycnal analysis (Buscaglia, 1971) suggests that the anticyclonic gyre of surface water in the subtropical South Atlantic extends to depths in excess of $1000 \mathrm{~m}$. Consequently, the flow of AAIW in the vicinity of the Rio Grande Rise crest may have a strong eastward component. Reid et al. (1977, figs. 9-10) also suggest an eastward flow component in the northern Argentine Basin in the depth region occupied by AAIW.

2) Direct current measurements within NADW between 2000 and $3500 \mathrm{~m}$ generally show a persistent southward flow, with mean speeds on the order of $2-8 \mathrm{~cm} / \mathrm{s}$ (Reid et al., 1977, table 1). Southward flow through the Vema Channel at these depths is also suggested by a narrow region of low silica values corresponding in position with the channel axis (Hogg et al., 1982, fig. 11).

3) At the latitude of the Vema Channel and Rio Grande Rise, the "reference level" (or "level or no motion") between northward-flowing AABW and southward-flowing NADW can be approximated by the potential density surface $\sigma_{4}=45.93$, or a potential temperature of $\theta=1.84^{\circ} \mathrm{C}$ (Hogg et al., 1982, fig. 8). This surface occurs at a depth near $3600 \mathrm{~m}$ in the Vema Channel axis and slopes gently down toward the east, where it intersects the western flanks of the Rio Grande Rise.

4) The topographic effects of the Vema Channel substantially alter the flow of AABW entering from the south. Within the channel axis, the flow is strong ( $>15$ $\mathrm{cm} / \mathrm{s}$ ) and persistently northward below $\sim 4000 \mathrm{~m}$, with a weaker northward flow extending up to perhaps 3600 $\mathrm{m}$. On the east flank of the channel, however, there is no evidence for northward flow, even though AABW is clearly present above the surface of the eastern marginal terrace (Fig. 2). Direct current measurements and dynamic computations (Hogg et al., 1982) suggest a bifurcation of the reference level over the eastern wall of the channel, and a weak but persistent southward flow of AABW that extends over the entire eastern terrace. Modeling studies (Hogg, in press) can explain this rather surprising interpretation in terms of the effects of the channel geometry in initiating this "eddy" of southward return flow within waters that are clearly of Antarctic origin. This important result emphasizes the fact that water properties and the mean flow field are not necessarily covarying in a simple way. Consequently, one must be careful to discriminate between geologic indices of water properties and indices that may be indicative of the flow field.

5) An increase in AABW production in its source regions around the Antarctic continent would correspond to a shallowing and/or an intensification of northward flow within the Vema Channel axis; at the same time, however, one would expect there might be an increase in southward flow in the return limb of AABW above the eastern terrace.

6) The total transport of AABW through the Vema Channel ranges from 2 to $6 \times 10^{6} \mathrm{~m}^{3} / \mathrm{s}$ (Hogg et al., 1982, fig. 10), with significant fluctuations occurring over a time span of several months.

7) AABW flow in the Brazil Basin may divide into two principal branches, one branch turning eastward to follow the relatively deep Rio Grande Fracture Zone (Gamboa and Rabinowitz, 1981), and another branch continuing generally northward to northeastward, paralleling the region's bathymetric contours toward the mound of sediments in the vicinity of DSDP Site 515 (Fig. 9). The flow of AABW decelerates markedly as it enters the Brazil Basin (Hogg et al., 1982), allowing the excessive load of suspended particulates (Biscaye et al., 1981) to be deposited.

\section{SEDIMENT FACIES}

Let us now consider the modern distribution patterns of the principal lithofacies in the southwestern Atlantic. These observations are based on coring by Lamont-Doherty research vessels on numerous cruises over the past two decades, plus more intensive coring programs by the vessels Charcot (GEOBRESIL expedition, 1973), Chain (Cruise 115, 1974), and Atlantis II (Cruise 107, 1980). Reports describing these cores include Le Pichon et al. (1971), Melguen and Thiede (1974), and Johnson et al. (1977). The discussion in this paper will consider only Recent lithofacies; a separate report by McCoy and Zimmerman (1977) uses available DSDP cores and Tertiary piston cores to map these lithofacies at various earlier time slices during the Cenozoic.

\section{Rio Grande Rise}

The topographic isolation of the Rise from sources of massive terrigenous sediment supply provides an environment for relatively uninterrupted pelagic sedimentation. The pelagic sediments are predominantly biogenic, and are highly calcareous with a very small siliceous component. The calcareous sediment can be conveniently divided into several characteristic facies:

1) At depths shallower than $1400 \mathrm{~m}$, the carbonate sediment is very coarse grained, consisting predominantly of foraminifers, pteropods, and shell fragments of reefal debris eroded from the adjacent shallow banks that cap the Rise (Fig. 2). The reefal material is Paleogene and Cretaceous; there is no evidence for Neogene or Quaternary shallow-water carbonate facies. Nannofossils and nonbiogenic components of silt and clay size are rare in these shallow depths. The sediment has such a high shear strength that, during extensive coring on Atlantic II Cruise 107, we were unsuccessful in more than 35 attempts to obtain a standard piston or gravity core at various sites between 700 and $1400 \mathrm{~m}$. Below $1400 \mathrm{~m}$, by contrast, virtually all of our coring attempts were successful.

2) Between 1400 and $3200 \mathrm{~m}$, nannofossils and foraminifers are present in roughly equal proportion, and pteropods are relatively abundant (at least in the upper several centimeters of the cores). The fine fraction (principally nannofossils) increases markedly below $1400 \mathrm{~m}$, giving greater cohesion to the sediment and facilitating core recovery. Pteropods disappear relatively abruptly at $3200 \mathrm{~m}$ (Melguen and Thiede, 1974).

3) Between 3200 and $4000 \mathrm{~m}$, the nonbiogenic portion of the sediment increases systematically as the cal- 
careous component begins to undergo selective dissolution (e.g., Thunell, 1981b). The shallower-dwelling spinose planktonic foraminifers begin to show some effects of corrosion, whereas the deeper-dwelling globorotalids remain well preserved. Although there is clearly some selective carbonate dissolution in this interval (Fig. 11), the most striking dissolution gradient occurs at the foraminifer lysocline at $\sim 4000 \mathrm{~m}$.

4) Below $4000 \mathrm{~m}$ on the flanks of the Rise, planktonic foraminifers rapidly become fragmented and eventually are dissolved completely. Nannofossils and benthic foraminifers are somewhat more resistant to corrosion, but even these forms rapidly disappear below $\sim 4250 \mathrm{~m}$. An exception is any region where massive down-slope sediment movement can occur, such as the system of canyons on the north flank of the Rise. Under these conditions, calcareous components from a wide range of depth intervals may be reworked and redeposited within distributory channels and fans at the foot of the Rise, and can remain protected from the corrosive effects of bottom water if they are buried deeply and rapidly enough.

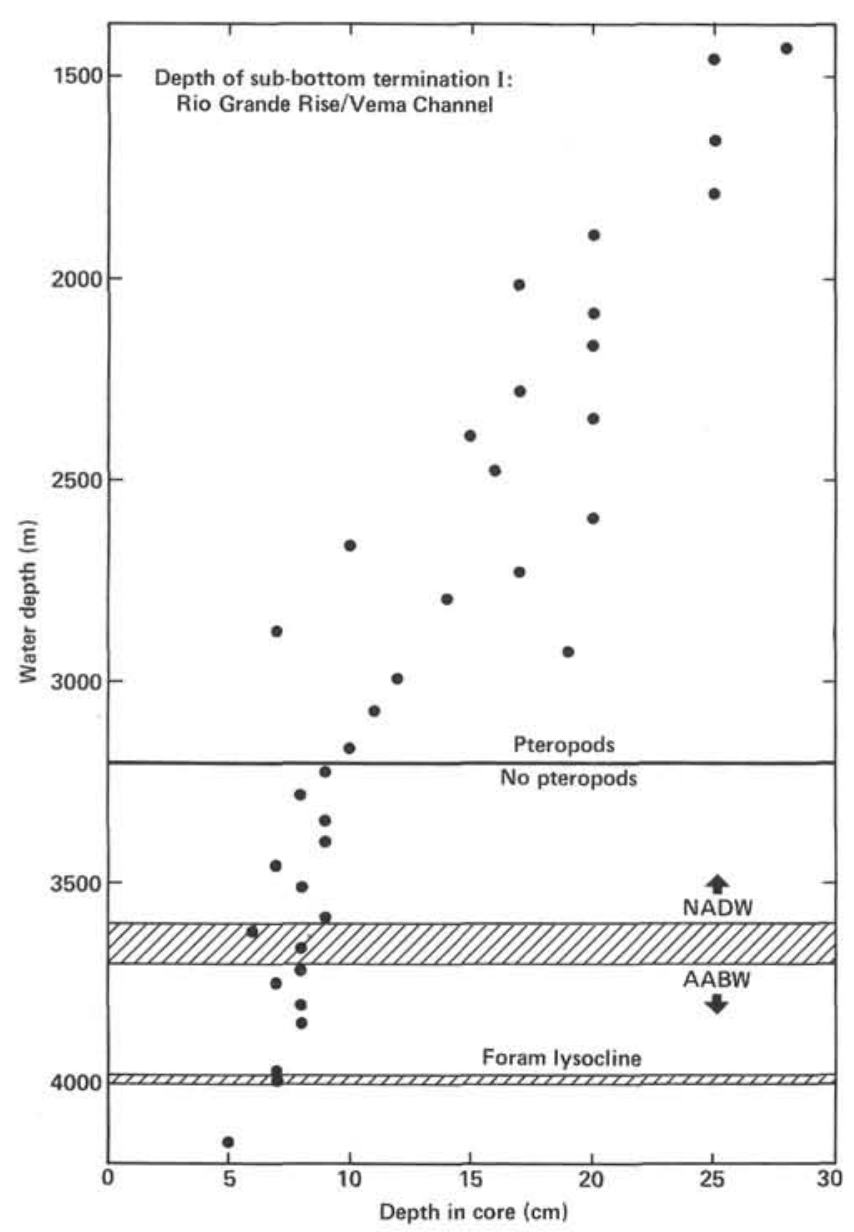

Figure 11. Holocene sediment facies on the Rio Grande Rise, based on extensive coring in 1980 (Atlantis II, 107). Major facies boundaries occur at $1400 \mathrm{~m}, 3200 \mathrm{~m}, 4000 \mathrm{~m}$, and $4200 \mathrm{~m}$ (see discussion in text). Note that the mean accumulation rate of Holocene sediments decreases systematically with depth, indicating selective dissolution of the more fragile calcareous components. NADW = North Atlantic Deep Water; AABW = Antarctic Bottom Water.

\section{Vema Channel}

Coring has not been as extensive within the Vema Channel below $4200 \mathrm{~m}$ as on the Rio Grande Rise to the east, principally because the persistence of strong bottom currents within the channel axis creates common hiatuses in the underlying strata, which make correlations and interpretations more difficult. In addition, the rapid disappearance of biogenic components below 4000 $\mathrm{m}$ often precludes the use of common biostratigraphic techniques. From the available core coverage, we can subdivide the channel facies into three principal regions: the channel floor, the channel walls, and the marginal terraces. Sediment on the channel floor is a zeolitic clay with common manganese nodules, encrustations, or micronodules. The depth of the channel thalweg varies from $\sim 4550 \mathrm{~m}$ at the sill near $31^{\circ} \mathrm{S}$ to $>4850 \mathrm{~m}$ near $30^{\circ} \mathrm{S}$ (Fig. 2). As a consequence of this considerable along-axis relief, the sediment accumulation is patchy, with solid manganese pavement in some regions, nodules interspersed with clay in other regions, and several tens of centimeters of pelagic clay elsewhere. The channel walls (depth $4300-4500 \mathrm{~m}$ ) have not been sampled because of the very steep relief in this region. It is likely that bottom current flow is persistently quite strong adjacent to both the eastern and western walls of the Channel below $4300 \mathrm{~m}$ (Hogg et al., 1982). Thus, we might expect to encounter outcropping lithified strata as well as intermittent patches of modern sediments at sites that are locally protected from strong flow. Farther upslope, the broad terrace bordering the Vema Channel on the east (Fig. 2) is capped by fields of regularly spaced sediment waves, features that are fairly characteristic of regions of fine-grained pelagic sediment deposition in the presence of persistent thermohaline current flow (Flood, 1980). The sediment of these regular bedforms is a hemipelagic clay, generally low $(<30 \%)$ in biogenic carbonate, with common silt-sized detrital mineral grains. Displaced Antarctic diatoms and clay minerals characteristic of high southern latitudes are common. The mean sediment accumulation rate appears to vary significantly on a local scale (kilometers or smaller). In some cores the upper Pleistocene rate exceeds $20 \mathrm{~m} / \mathrm{m}$.y., and elsewhere on the terrace, the upper Pleistocene sediment is largely missing. A likely explanation for this apparently irregular accumulation pattern is that the sediment waves are migrating, with preferential sediment accumulation occurring on the "upstream" flank of the waves. Although we are not yet able to specify whether the waves flanking the Vema Channel are in fact lineated and migrating (Flood, 1980), we strongly suspect that this is the case, and that a similar pattern of preferential erosion and deposition is present on the "upstream" and "downstream" flanks of the waves, respectively. Also, there is a noteworthy corresponding terrace of sediment waves that is $600 \mathrm{~m}$ shallower on the west flank of the channel than on the east flank (Fig. 2). This is consistent with the oceanographic evidence pointing to strong cross-channel asymmetry in the flow field (Hogg et al., 1982) and suggests a dynamic similarity between the flow at $3650 \mathrm{~m}$ on the west flank and that at $4250 \mathrm{~m}$ on the east flank. 


\section{Brazil Basin and Argentine Basin}

Sediment distribution patterns and sources in these deep regions have been interpreted on the basis of seismic profiling (see Ewing and Lonardi, 1971; Kumar et al., 1979) and echo-character mapping (e.g., Damuth and Hayes, 1977), with relatively little information available from coring or drilling. In general, both of these basins are characterized by very high influxes of terrigenous sediments along their western margins, and some redistribution of sediment along the margin or interior of the basins by the deep western boundary current (DWBC). The effects of AABW flow in redistributing sediment should be notably greater in the Argentine Basin than in the Brazil Basin, since the Vema Channel allows a volume transport of only about $2-6 \times 10^{6} \mathrm{~m}^{3} / \mathrm{s}$ of northward-flowing AABW to enter the Brazil Basin (Hogg et al., 1982), compared to the estimated transport in the Argentine Basin of $\sim 30 \times 10^{6} \mathrm{~m}^{3} / \mathrm{s}$ (Wright, 1969). There is, in all likelihood, a strong clock-wise return flow of the DWBC in the eastern Argentine Ba$\sin$, and this flow may be responsible for creating fields of enormous sediment waves in the interior of the basin. The Rio Grande Rise is clearly a major supplier of biogenic carbonate debris to the southern Brazil Basin via several canyon systems, including a major channel that enters the basin near $35^{\circ} 30 \mathrm{~W}$ (Johnson and Peters, 1979). The Argentine Basin, by contrast, seems to be relatively free of erosional products from the Rio Grande Rise. Both basins are characterized by high net accumulation rates ( $>20 \mathrm{~m} / \mathrm{Ma})$, and precise stratigraphic control is quite difficult because of extensive reworking. Drilling into the sediments of these basins, which predate the initiation of thermohaline current flow, should yield important information on the timing of the onset of deep circulation.

\section{SEDIMENT-CURRENT INTERACTIONS AND PALEOCEANOGRAPHY}

Marine geologists have recognized for nearly two decades that sedimentation in many regions of the deep ocean is inextricably linked to the properties and flow characteristics of the overlying water column. Yet it has been only within the last several years that geologists have combined their observation efforts with those of physical oceanographers in an attempt to quantify and predict the nature of sediment-current interactions in a particular setting. (For recent review articles see Arthur, 1979; Berger, 1979.) These studies are generally one of two distinct types, according to the spatial and temporal scales under consideration. Some experiments (e.g., HEBBLE; see Hollister et al., 1980) focus upon benthic boundary layer flow dynamics and bedform response over a relatively limited spatial extent. Other experiments (e.g., the Vema Channel Project of Johnson et al., 1981) have chosen to obtain and interpret oceanographic and geologic observations over a much broader spatial scale, rather than attempting to describe sediment-current interactions at any instant at a fixed point. It is important to recognize that one approach is not inherently "better" than the other. At a given focal set- ting of observations, one simply may obtain information that is not obtainable at a different focal setting.

In order to examine properly the paleoceanographic drilling objectives of DSDP Leg 72, we now consider the concept of "teleconnective linkages" as applied to the deep-ocean circulation. In a previous section of this paper, the major water masses and flow patterns in the southwestern Atlantic were outlined. It is necessary to treat these water masses as highly interactive rather than independent. The task is finding a satisfactory representation for these interactions, rather than resorting to hopeless armwaving and declarations that "everything is related to everything else." In the following discussion, I've summarized three types of teleconnective linkages that can be used to represent the interactive dynamics of the water masses of the southwestern Atlantic.

\section{The Concept of "Teleconnective Linkages"}

The term "teleconnections" (Wyrtki, 1973; Johnson, 1982) implies a recognition that the set of conditions in a particular geographic area may be sequentially linked to, and perhaps controlled by, one or more forcing functions occurring a great distance away. Commonly there are several intermediate steps or pathways that are essential components of a given linkage. These components are in some instances configured in a linear and irreversible sequence of events; in other instances the configuration consists of one or more feedback loops. Geographic and tectonic configurations are essential boundary conditions to be considered in understanding these linkages. Moreover, the deposition record may contain numerous geologic "fingerprints," which identify one or more of the linkages in a teleconnection, and may therefore provide further information about the initiation and development of the teleconnection.

Three types of teleconnections appear to describe the interactive dynamics of water masses contributing to the deep circulation in the southwestern Atlantic. Let us consider the essential characteristics of each type, and how each of these representations of water mass interaction may be reflected in the geologic record.

\section{Reinforcing Teleconnection (example: Mediterranean outflow + Norwegian surface water $\rightarrow$ North Atlantic Deep Water)}

The eastern North Atlantic provides an excellent illustration of this type of teleconnection (Fig. 12). The outflow of high-salinity water from the Mediterranean has been traced not only westward (Worthington, 1976) but also northward in an eastern boundary current, which apparently extends as far as the Iceland-Scotland Ridge (Reid, 1978, 1979). This influx of high-salinity water into the Norwegian Sea from the south mixes with the cold $\left(<-1.5^{\circ} \mathrm{C}\right)$ ambient surface water, and a deep thermohaline outflow cascades southward over the sills of the Greenland-Iceland-Scotland Ridge to form North Atlantic Deep Water (Broecker and Takahashi, 1980). The formation of modern NADW requires one or more sources of high-salinity near-surface water from the south. Thus the conditions required for NADW formation in high latitudes include not only the oceanography 


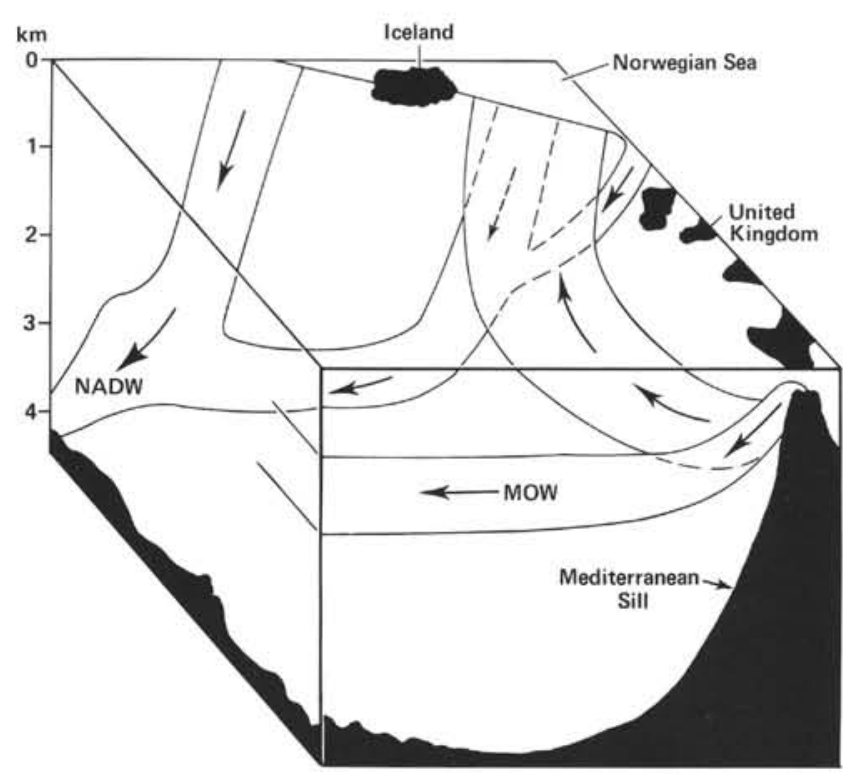

Figure 12. Schematic illustration of the reinforcing teleconnection in the northeastern Atlantic (after Johnson, 1982). The production of North Atlantic Deep Water (NADW) requires the advection of high-salinity (e.g., Mediterranean) water into the Norwegian Sea, where it cools and sinks to form NADW. MOW = Mediterranean outflow water.

at the "source region" (i.e., the Norwegian Sea), but also the evaporation/precipitation budget in the subtropical North Atlantic and the sill depth of the Mediterranean, several thousand kilometers distant from the Norwegian Sea.

There is some evidence that the saline Mediterranean outflow may be a necessary as well as a sufficient condition for NADW production in the Norwegian Sea. Modern NADW is oxygen rich and $\mathrm{CO}_{2}$ poor, and sediments beneath NADW are generally marked by excellent carbonate preservation (Berger, 1978). The Mediterranean was a closed basin and tectonically isolated from the North Atlantic during the Messinian Stage of the late Miocene, approximately 5-6.5 Ma (Ryan et al., 1974; Ryan, 1976). Sediment cores of this age from the tropical and subtropical Atlantic are marked by "spikes" of intense carbonate dissolution (Ryan et al., 1974; Thunell, 1981a) or hiatuses (Supko, Perch-Nielsen et al., 1977). Thus the late Miocene "dissolution spike" in the Atlantic may reflect the shutting off of oxygen-rich NADW and its replacement by a more stagnant, $\mathrm{CO}_{2}$ rich, corrosive water mass. This shutting off in turn was caused by the brief cessation of the teleconnection between the Mediterranean outflow and the Norwegian Sea.

A more convincing documentation of this particular teleconnection during the geologic past will require the identification of a component in the geologic record that will "fingerprint" the hypersaline Mediterranean outflow. To date, however, micropaleontologic or geochemical indices of salinity shifts of $1-2 \%$ have yet to be demonstrated.

\section{Lateral "Blocking"/Redirection (example: Circumpolar Water + North Atlantic Deep Water)}

The mid-depth circulation of the southwestern Atlantic between $30^{\circ} \mathrm{S}$ and $45^{\circ} \mathrm{S}$ is an excellent example of this type of teleconnection (Fig. 13). The eastward-flowing CPW is deflected northward into the Argentine Basin (via the Coriolis force) after exiting the Drake Passage, and intercepts the motion of southward-flowing NADW. The two waters are of comparable density, and as a result NADW splits CPW into an upper branch (UCPW) and a lower branch (LCPW) (Reid et al., 1977). The bifurcation of CPW is best illustrated on the GEOSECS profiles of dissolved oxygen or total $\mathrm{CO}_{2}$ in the western Atlantic (Bainbridge, 1980; Kroopnick, 1980, fig. 6). The intersection of the two water masses suggests that one is indeed blocking the penetration of the other. The abrupt drop in salinity within the core of NADW between $35^{\circ} \mathrm{S}$ and $40^{\circ} \mathrm{S}$ suggests that NADW is effectively blocked from further southward penetration. Moreover, were it not for the presence of NADW, CPW would be able to penetrate substantially farther north into the equatorial Atlantic, as is the case with the AAIW.

In addition to the mutual blocking of the two water masses, a second aspect of this particular teleconnection is the entrainment of NADW within the eastward circumpolar flow. North of $35^{\circ} \mathrm{S}$, NADW penetration into the South Atlantic is zonally asymmetric, with a well-defined core of highest salinity water within $\sim 500 \mathrm{~km}$ of the South American continent (Reid et al., 1977, figs. $3 a, 4 a)$. One would therefore expect that, in the absence of circumpolar flow, high salinities at intermediate depths would not be reflected substantially in the southeastern Atlantic or farther east. Reid and Lynn (1971), however, have used isopycnal analysis to trace high-

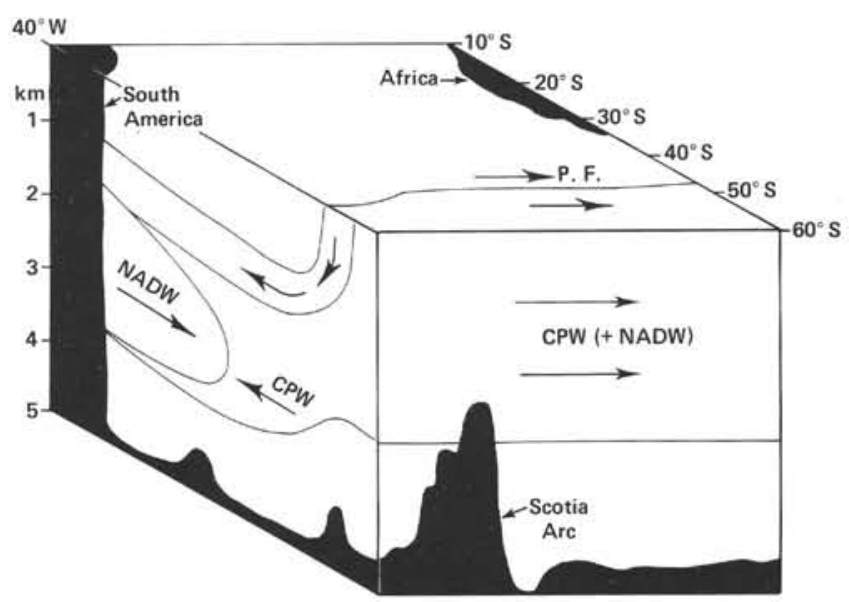

Figure 13. Schematic illustration of the blocking and redirection of North Atlantic Deep Water (NADW) by Circumpolar Water (CPW) in the southwestern Atlantic (after Johnson, 1982). The presence of eastward-flowing CPW blocks the southward penetration of NADW near $45^{\circ} \mathrm{S}$ and advects high-salinity water eastward into the southern Indian and Pacific oceans. P. F. $=$ Polar Front. 
salinity water of North Atlantic origin along an appropriate density surface $\left(\sigma_{4}=45.92\right)$ into the Indian and Pacific oceans. Consequently the contribution of NADW to the salinity of the deep Indian and Pacific oceans is a direct reflection of the "blocking" teleconnection in the southwestern Atlantic and the presence of circumpolar flow.

Each of the two aspects of the NADW/CPW teleconnection (i.e., lateral "blocking"' and redirection) should be well represented in the geologic record at strategic locations, thereby enabling us to determine when this particular teleconnection was initiated and how it has evolved during the recent past. The present-day zone of "blocking" of NADW and CPW (near $30^{\circ} \mathrm{S}$ ) is clearly reflected in vertical profiles of dissolved $\mathrm{O}_{2}$ and $\mathrm{CO}_{2}$, which distinguish relatively old $\mathrm{CPW}$ from the recently oxygenated NADW. Strong oxygen minima mark both the upper and lower branches of CPW, with high oxygen in the intervening NADW (Reid et al., 1977). The pelagic carbonate facies of the Rio Grande Rise span the total range of sharp transitions in water properties, and therefore should reflect the present-day vertical extent of the major water masses and their sense of migration during the past (Melguen and Thiede, 1974; Johnson et al., 1977). The essential step is to identify lithologic, paleontologic, or geochemical components within Recent sediments that can clearly discriminate between the properties of UCPW, NADW, and LCPW. Then these indices can be applied to dated core material to interpret how the zone of "blocking"' has evolved into its present configuration. Times of intensification of NADW relative to CPW should be marked by a shallowing of UCPW (and its associated geologic indices), a deepening of LCPW, and farther southward penetration of NADW. The opposite sense of migration should occur during a relative intensification of circumpolar flow.

Farther to the south, the Falkland Plateau and Maurice Ewing Bank lie beneath present-day circumpolar flow near the Polar Front (Gordon, 1971). These topographic rises have been drilled and cored fairly extensively (e.g., Barker, Dalziel, et al., 1977; Ludwig, Krasheninnikov, et al., 1980; Ciesielski et al., 1982), and may record the opening of Drake Passage, the onset of circumpolar flow, and the initiation of the "blocking", aspect of the NADW/CPW teleconnection. Before the opening of the Drake Passage, NADW (or its equivalent) may have extended much farther south in the Argentine Basin, possibly to the latitude of the Falkland Plateau. A number of drilling results are pertinent to the documentation of this hypothesis. For instance, Site 513 in the southeastern Argentine Basin contains a marked facies contrast near the Oligocene/Miocene boundary, with pelagic carbonate in the Paleogene evolving to carbonate-free siliceous sediments that have persisted through the Neogene (Ludwig, Krasheninnikov, et al., 1980, fig. 2). The excellent preservation of Oligocene calcareous sediment at this relatively deep location suggests the presence of highly oxygenated water through much of the lower water column; thus, an Oligocene equivalent of NADW may have extended far into the southwest Atlantic to the latitude of the Falkland Pla- teau. The initiation of circumpolar flow after the opening of the Drake Passage then blocked the extent of NADW to a more northerly subtropical position. In order to verify this hypothesis, one must select geologic indices that discriminate between the effects of a young water mass of northern origin (e.g., NADW) from a southern water mass with comparable properties. For mid-Tertiary "NADW" in the southwest Atlantic, a clear marker that denotes advection from lower latitudes is needed.

The presence of "blocking" in one region (e.g., the southwestern Atlantic) necessarily implies that blocking/ redirection has failed to occur at potential locations "upstream." For instance, equatorial flow through the Tethyan seaway during the middle Tertiary (Berggren and Hollister, 1974; Kennett, 1977) could have been a significant contributing factor in redirecting NADW away from the South Atlantic. If the east-to-west Tethyan flow had extended to sufficient depth in the western Atlantic, then NADW would have been effectively blocked from penetration into the South Atlantic, and a Tethyan/NADW teleconnection would have diverted relatively young NADW directly into the northeastern Pacific via the Caribbean. On the other hand, if the Tethyan equatorial flow had been restricted to relatively shallow depths $(<2 \mathrm{~km})$, NADW would have continued uninterrupted into the South Atlantic. A modern example of such a "failed blocking" is the northward flow of Weddell Sea Bottom Water through the Scotia Arc complex beneath the shallower circumpolar flow (Gordon, 1971; Georgi, 1981).

The redirection of NADW by CPW is clear in modern oceanographic data (Reid and Lynn, 1971), and there is some geologic evidence concerning the extent of such redirection during the past. If NADW production had been substantially reduced during glacial intervals (Streeter and Shackleton, 1979), then this reduction should be reflected "downstream" within CPW as well as in the abyssal Atlantic. Corliss (1982) has analyzed benthic foraminiferal assemblages in well-dated piston cores from the southeastern Indian Ocean beneath the present-day circumpolar flow. He found that glacial-age sediments in this region are characterized by a benthic assemblage that is absent in such sediments beneath the modern Circumpolar Current. The same assemblage is also found in glacial-age material from the North Atlantic and has been interpreted to reflect the reduction or cessation in production of well-oxygenated NADW (Streeter and Shackleton, 1979). A radiolarian species, Cycladophora davisiana, also shows similar glacial/interglacial abundance variations in the North Atlantic and in the Southern Ocean (Morley and Hays, 1979). Thus it is likely that the glacial Circumpolar Water had distinctly different properties than modern CPW, and that this difference may have been a direct reflection of NADW's rate of production and downstream incorporation into $\mathrm{CPW}$.

\section{Wedging (example: Antarctic Bottom Water/ North Atlantic Deep Water)}

Here the interaction between two water masses occurs not in a single critical geographic region, but along 
a near horizontal or slightly inclined mixing zone with lateral dimensions of up to several thousand kilometers and thickness of up to several hundred meters. In this instance, the vertical extent of each water mass as well as its horizontal extent is likely to vary with time. These waters may be moving in opposite directions, one of the two may be relatively motionless, or they may be moving in the same direction. What is required is a sufficiently high horizontal velocity contrast between the two water masses, perhaps (but not necessarily) coinciding with the depth interval where the density gradient between the two is sharpest. (Both water masses could of course be stationary and have the density front maintained, as is the case in restricted basins such as the Red Sea and Black Sea. The discussion here considers only the openocean situation where there is commonly some relative motion between the two water masses.)

The "wedging" type of geometry is well represented in the abyssal circulation of the tropical and subtropical western Atlantic (Fig. 14). Here, southward-flowing NADW overrides the denser northward-flowing AABW, with a broad zone of turbulent mixing between the "cores" of the two water masses. This mixing zone, the top of which corresponds approximately with the "twodegree discontinuity" (Wüst, 1936; Broecker et al., 1976), slopes upward from a depth of $4 \mathrm{~km}$ at $40^{\circ} \mathrm{N}$ to $3.2 \mathrm{~km}$ at $30^{\circ} \mathrm{S}$. The depth intervals spanned by this mixing zone, and perhaps its slope as well, are presumably controlled by the relative rates of production of the two water masses in polar regions. Times of NADW intensification would correspond to deepening and southward penetration of the zone, with the opposite sense of migration occurring during times of $\mathrm{AABW}$ intensification.

In one sense, the teleconnection concept is not quite satisfactory as a description of the wedge geometry (Fig. 14). The term "teleconnection" (in the context of this paper) implies that there is a spatial and temporal sequence of events that link two or more water masses, but the sequence implied for the configuration shown in

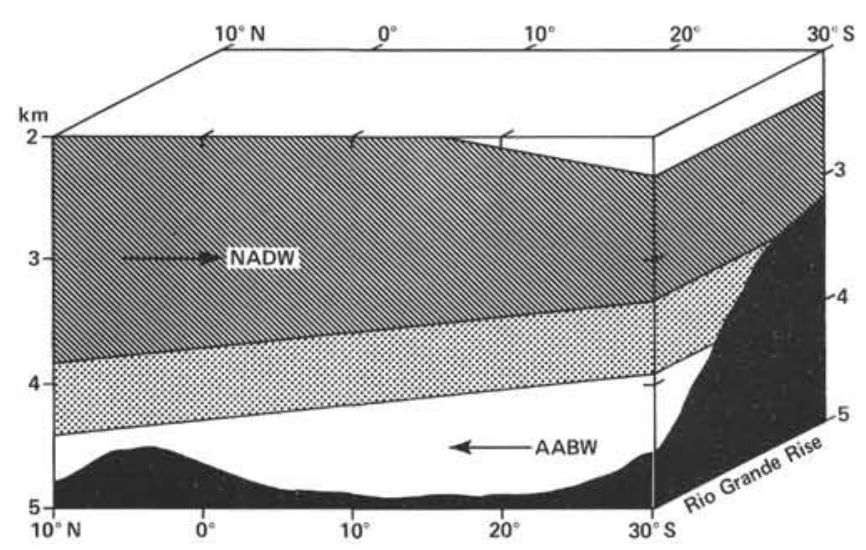

Figure 14. Schematic illustration of the wedging geometry of North Atlantic Deep Water (NADW) and Antarctic Bottom Water (AABW) in the Vema Channel region (after Johnson, 1982). The transition zone between the "cores" of the two water masses is at least $1 \mathrm{~km}$ in thickness and migrates vertically in response to changing rates of production of the two water masses.
Figure 14 is not clear. Yet, the teleconnection concept probably is appropriate here, because the region of interaction between the two water masses in a "wedge" is spatially much more extensive than for either of the first two examples. The transition zone may span an entire ocean basin (e.g., the western Atlantic) rather than being restricted to a single well-defined zone of limited extent. Moreover, the interaction between the two water masses may occur not only through vertical mixing within the water column, but also at the downstream terminations of each water mass. For instance, the high-silica values characteristic of $\mathrm{AABW}$ in the western Atlantic have been identified within the core of the southwardflowing DWBC near Cape Hatteras (Needell, 1980; Richardson et al., 1981), thus clearly indicating the contribution of AABW to the southward-flowing DWBC. A comparable situation is present in high southern latitudes near the source region of AABW where high-salinity water is present at mid-depths $(500-600 \mathrm{~m})$ seaward of the shelf edge of the Weddell Sea. These high salinities are essential constituents of newly formed AABW (Seabrooke et al., 1971; Carmack and Foster, 1975) and have their ultimate source in the North Atlantic or within NADW (Foster and Middleton, 1980, p. 376; Schnitker, 1980a, 1980b). Because of the mutual dependence of these two water masses upon each other, I suggest that the teleconnection concept is appropriate to represent the interactive dynamics of $\mathrm{AABW}$ and NADW. The total region of interaction of the two water masses spans the entire western Atlantic, and probably involves differential roles of various mixing processes (e.g., advective versus diffusive) at different locations. The sequence of events in the overall configuration may be best represented by one or more feedback loops rather than a linear progression of events from one region irreversibly to the next in sequence. Nevertheless, the prefix "tele" seems appropriate here, simply due to the spatial extent over which the two water masses are contributing to each other.

\section{Geologic "Fingerprints" of Paleoceanography in the Southwestern Atlantic}

The NADW/AABW transition zone in the southwestern Atlantic is broad, spanning $\sim 1 \mathrm{~km}$ of the lower water column. Yet within this broad depth range, there are several water column characteristics that exhibit welldefined gradients, apparently restricted to a relatively narrow depth intervals. Table 3 lists nine properties of the southwestern Atlantic water column (near $30^{\circ} \mathrm{S}$ ) that one might generally associate with the NADW/AABW transition zone. The order in which these gradients are listed corresponds with their approximate vertical position near the Vema Channel. There may be significant small-scale variations in the "mean" depths of some of these properties, particularly in the vicinity of local topographic irregularities. Yet we would expect the mean positions of these water property indices to be stable within an area of appropriately chosen dimensions. The items listed in Table 3 are not intended to be all-inclusive, and two or more of them may be found to coincide when more observations become available. For the pres- 
Table 3. Oceanographic gradients in the NADW/AABW transition zone in the Vema Channel near $30^{\circ} \mathrm{S}$ in the southwestern Atlantic (modified from Johnson, 1982).

\begin{tabular}{lcc}
\hline \multicolumn{1}{c}{ Property } & $\begin{array}{c}\text { Approximate } \\
\text { depth } \\
\text { near } 30^{\circ} \mathrm{S}(\mathrm{m})\end{array}$ & \multicolumn{1}{c}{ Reference } \\
\hline $\begin{array}{l}\text { Hydrographic discontinuity } \\
\text { (TDD) } \\
\text { " } 50 \% \text { line" }\end{array}$ & 3200 & $\begin{array}{c}\text { Broecker et al., 1976, } \\
\text { table } 1\end{array}$ \\
$\begin{array}{l}\text { Reference level }(\overline{\mathrm{V}}=\mathrm{O}) \\
\text { Broecker and Takahashi, } \\
\text { 1980, fig. 7 } \\
\text { Hogg et al., 1982, } \\
\text { fig. 8 }\end{array}$ \\
$\begin{array}{l}\text { Upper limit of nepheloid layer } \\
\text { Maximum velocity shear }\end{array}$ & 3600 & $\begin{array}{c}\text { Johnson et al., 1976; } \\
\text { Biscaye et al., 1981 }\end{array}$ \\
$\begin{array}{l}\text { Critical carbonate ion } \\
\text { concentration }\end{array}$ & $3700-4100$ & $\begin{array}{c}\text { Hogg et al., 1982, } \\
\text { fig. 8 }\end{array}$ \\
$\begin{array}{l}\text { Midpoint in benthic } \\
\text { thermocline }\end{array}$ & 3900 & $\begin{array}{c}\text { Broecker and Takahashi, } \\
\text { 1978, fig. 15 }\end{array}$ \\
$\begin{array}{l}\text { Stability maximum } \\
\text { Upper limit of excess } \\
\text { radon 222 }\end{array}$ & 4200 & $\begin{array}{l}\text { Johnson et al., 1976 } \\
\text { Reid et al., 1977 } \\
\text { fig. 5a }\end{array}$ \\
\hline
\end{tabular}

ent, these properties may be taken as representative of the kinds of water column gradients that are present within the "wedging" configuration of two adjacent water masses.

Table 3 illustrates that the concept of a sharp boundary between NADW and AABW is meaningless. Moreover, it is not clear which of the water column properties listed in the table would be the best property to measure in order to define the transition zone. Each property conveys important information, yet individually is unsatisfactory as a complete description of the transition zone. For instance, the two-degree discontinuity is indeed the most fundamental feature in property-property diagrams of the abyssal western Atlantic (Broecker et al., 1976, fig. 3). Yet such diagrams contain no information at all about the quantity of water of a particular type, its flux through a given cross-sectional area, or the nature of the density stratification in the water column. Similarly, a vertical profile of the relative concentration of suspended particulates (nephels) contains some information about vertical eddy diffusivity in the turbulent bottom boundary layer, yet such a profile need not be at all indicative of mean current speed (given by $\bar{u}$ ). Instead, the distribution of nephels or other bottom tracers in the lower water column may be more nearly a measure of departures from the mean conditions (such as the rootmean square value of the fluctuating components of velocity or $\sqrt{\left(\mathrm{u}^{\prime}\right)^{2}}$, where $\left.\mathrm{u}^{\prime}=\mathrm{u}-\overline{\mathrm{u}}\right)$. A similar argument applies to each of the remaining items listed in Table 3. There is information contained in each item about the water column in the NADW/AABW transition zone, yet it is important to realize the inferences that cannot be drawn from any particular one of these types of data alone.

Let us now examine the geologic indices that have been identified within the NADW/AABW "wedge." Extensive coring in the Vema Channel/Rio Grande Rise area in the southwestern Atlantic in 1974 and 1980 revealed that a wide variety of geologic parameters have significant gradients within the NADW/AABW transition zone; many of these parameters have been interpreted in dated core material in terms of vertical migrations of the transition zone during the past. Table 4 lists several of these indices, and the approximate location of each transition zone in core top samples from the Vema Channel (near $30^{\circ} \mathrm{S}$ ). The geologic indices (Table 4) appear to follow a pattern comparable to that of the water column properties (Table 3 ): there is a very broad overall transition zone at least $1 \mathrm{~km}$ in thickness within which sharp gradients occur, yet each of these gradients individually may be confined to a very narrow depth interval, perhaps $100 \mathrm{~m}$ or less in thickness.

I have intentionally separated the water column observations in Table 3 from the geologic indices of Table 4 , even though it is tempting to suggest associations between corresponding items in the two data sets. For instance, the use of the critical carbonate ion concentration (CCIC) appears to be a very successful predictor of the depth of the foraminifer lysocline and circumvents the uncertainties associated with determining $\mathrm{K}_{\mathrm{sp}}$ for calcite (Broecker and Takahashi, 1978). For most of the other geologic indices, however, it is not yet possible to correlate each to a definitive water column characteristic, because of the insufficient spacing of water column observations and reliable core-top data within the depth intervals of interest.

\section{Critical Paleoceanographic Drilling Objectives in the Southwestern Atlantic}

The physiographic and oceanographic setting of the Vema Channel-Rio Grande Rise area provides a number of prime drilling targets for paleoceanographic objectives. Three characteristics have especially generated much interest in the southwestern Atlantic near $30^{\circ} \mathrm{S}$ : sharp vertical gradients between several major water masses, draping pelagic sediments on the Rio Grande Rise over depth intervals encompassing all of these water masses, and the strong thermohaline flow within the

Table 4. Geologic parameters with sharp gradients in the NADW/ AABW transition zone in the southwestern Atlantic near $30^{\circ} \mathrm{S}$, modified from Johnson (1982). Each of these "fingerprints" is a potential index of paleocirculation.

\begin{tabular}{|c|c|c|}
\hline Geologic index & $\begin{array}{l}\text { Approximate depth of } \\
\text { steepest gradient } \\
\text { near } 30^{\circ} \mathrm{S}(\mathrm{m})\end{array}$ & Reference \\
\hline Pteropod lysocline & 3400 & $\begin{array}{l}\text { Melguen and Thiede, 1974; } \\
\text { Thunell, 1981b }\end{array}$ \\
\hline${ }_{\delta}{ }^{13} \mathrm{C}$ in benthic foraminifers & $3500-3800$ & Curry and Lohmann, 1982 \\
\hline $\begin{array}{l}\text { Trace element geochemistry } \\
\text { of benthic forams }\end{array}$ & $3500-3800$ & Boyle and Keigwin, 1982 \\
\hline Clay mineral facies & 3800 & Jones and Robinson, 1981 \\
\hline Displaced Antarctic diatoms & 3900 & $\begin{array}{l}\text { Johnson et al,, 1977; } \\
\text { Burckle and Clarke, } 1981\end{array}$ \\
\hline $\begin{array}{l}\text { Benthic foraminiferal as- } \\
\text { semblages }\end{array}$ & 4000 & $\begin{array}{l}\text { Lohmann, 1978; Peterson and } \\
\text { Lohmann, } 1982\end{array}$ \\
\hline Foraminiferal lysocline & 4000 & $\begin{array}{l}\text { Broecker and Takahashi, } \\
\text { 1978; Thunell, 1981b }\end{array}$ \\
\hline $\begin{array}{l}\text { Stratigraphic continuity; } \\
\text { upper limit of erosional } \\
\text { unconformities }\end{array}$ & 4000 & $\begin{array}{l}\text { Johnson et al., 1977; } \\
\text { Williams and Ledbetter, } \\
1979\end{array}$ \\
\hline $\begin{array}{l}\text { Carbonate compensation } \\
\text { depth }\end{array}$ & 4250 & $\begin{array}{l}\text { Johnson et al., 1977; } \\
\text { Berger, } 1978\end{array}$ \\
\hline $\begin{array}{l}\text { Particle size (noncarbonate } \\
\text { fraction) }\end{array}$ & 4250 & Ledbetter, 1979 \\
\hline $\begin{array}{l}\text { Magnetic grain fabric } \\
\text { alignment }\end{array}$ & 4250 & Ellwood and Ledbetter, 1977 \\
\hline
\end{tabular}


confines of the Vema Channel. The following paleoceanographic objectives were initially targeted for drilling on Leg 72. Some of these have been addressed in chapters in this volume using the recovered cores, and others will require additional coring because of erosional hiatuses or discontinuities in our core recovery.

1) Initiation of $A A B W$ flow. There is considerable paleontologic and stable isotopic evidence supporting the notion that there was a major global oceanographic event near the Eocene/Oligocene boundary (e.g., Savin et al., 1975; Benson, 1975; Kennett and Shackleton, 1976; Kennett, 1977; Keigwin, 1980; Corliss, 1981; Miller et al., 1982; Miller and Curry, 1982). A common inference is that the modern deep thermohaline circulation may have been initiated at this time, perhaps in association with the geographic separation of the Antarctic continent and the initiation of strong circumpolar flow. As pointed out earlier in this paper, however, geologic indices of shifts in paleotemperature or other water properties should not be used to infer changes in flow direction or intensity. Water properties and the flow field at any point may covary, but this need not be the case. Thus, inferences about the initiation of AABW flow should rely upon geologic indices of water column advection. The Vema Channel and southern Brazil Basin are prime target regions, because AABW transports a significant quantity of suspended material (Johnson et al., 1976); consequently, a number of the sediment components which are redeposited from the suspended load may prove to be a reliable index of the presence of AABW flow (Table 4).

2) Timing of the initiation of NADW. There is considerable seismic stratigraphic and paleontologic evidence from the northwestern Atlantic that points to the initiation of a major DWBC at approximately the Eocene/Oligocene boundary (e.g., Miller and Tucholke, in press). If indeed $\mathrm{AABW}$ and NADW were both initiated near this time, then it is more important to discriminate between the geologic effects of these two water masses and establish which event preceded the other. Such a distinction is difficult to make in the northwestern Atlantic, since the two water masses are of comparable density, and "tongues" of high-silica AABW evidently become entrained in the southward-flowing DWBC off eastern North America (Richardson et al., 1981). In the southwestern Atlantic, by contrast, AABW is sufficiently cold and dense to underlie NADW (Fig. 14), and thus, strategically positioned cores could potentially discriminate between major episodes of the production of the two water masses.

3) Identification of major pulses of $A A B W$ and $N A D W$. The success of the CLIMAP project (Hays et al., 1976) demonstrates that the proper time-space reference frame for understanding oceanic teleconnections is the frequency-response and phase-response spectrum (Imbrie and Imbrie, 1980). If a particular system has no cyclicity at all, it is an unpredictable enigma and an unreproducible experiment. If it does have cyclicity, we should measure and quantify each component's amplitude and phase and then relate these quantities to other components whose own frequency response indicates a coherent connection. This quantitative approach is of particular importance because one's intuition is not always reliable in anticipating either the way in which a set of covarying parameters are linked or the spatial scales over which these linkages are applicable. For example, glacial maxima in North America are apparently preceded by warm surface water temperatures in the adjacent western North Atlantic (Ruddiman et al., 1980). This perhaps surprising conclusion places major constraints on the necessary conditions for supplying moisture to a growing ice sheet and the probable source regions for this moisture. Conventional piston cores and rotary-drilled cores in soft sediment have proved suitable for time-series analysis only in a few instances within limited stratigraphic intervals where continuous deposition and essentially complete core recovery could be verified. The continuing technical improvements in the recovery of undisturbed cores (e.g., Glomar Challenger's hydraulic piston corer) will be crucial in providing material appropriate to this essential interpretive procedure.

4) Effects of glaciation upon deep thermohaline flow. Stable isotopic evidence gives us a detailed record of eustatic sea level and global ice volume over the past million years. But we are not yet able to produce a correspondingly detailed history of deep thermohaline current flow. One might anticipate that the abyssal circulation history will prove to be as complex as the record of global ice volume, yet the frequency response need not be at all similar for the two. The numerous pathways of energy exchange in the ice/ocean/atmosphere system that control global sea level are probably not of equal importance in their contributions to thermohaline current generation. The use of the HPC in suitable regions of continuous deposition will be required to obtain adequate time-series observations for this purpose. In addition, we need to examine the abyssal ocean for first-order changes in flow pattern that may have accompanied the major episodes of ice buildup in the middle Miocene (Savin et al., 1975) and in the Pliocene (Shackleton and Opdyke, 1977).

5) Role of "threshold events" in controlling deep thermohaline flow. The concept of teleconnective linkages requires that we consider tectonic boundary conditions at locations quite remote from the area of interest. The change of a critical sill or passage beyond a critical "threshold" value of shallowness or depth may lead to very abrupt readjustments in global circulations, even if the associated vertical and lateral tectonic readjustments have occurred relatively continuously over a long period of time. In the geophysical reconstructions of the paleoposition and paleodepth of crustal plates, there usually are uncertainties of several million years in time estimates of the beginning of crustal rifting or collision (e.g., Barker and Burrell, 1977). With a much greater correlation precision potentially available in sequences dated biostratigraphically and paleomagnetically, we can begin to contribute evidence pertinent to geophysical as well as oceanographic reconstructions of the past. 


\section{SUMMARY}

The southwestern Atlantic near $30^{\circ} \mathrm{S}$ is a region of pronounced vertical gradients in the water column where several major water masses converge. These water masses are denoted by "core" regions up to a few hundred meters in thickness, with transition zones several hundred meters thick separating these core regions. The concept of sharp boundaries between water masses should be abandoned because of the highly interactive nature of the water masses.

The water masses of the southwestern Atlantic may be understood in terms of three types of teleconnective linkages. These are designated: (1) reinforcing, (2) lateral blocking/redirection, and (3) wedging. A teleconnective linkage between water masses may in some instances by configured linearly and respond in an irreversible fashion. In other instances, the linkage is not unidirectional, but may include one or more feedback loops representing the dependence of each water mass upon the properties and extent of the other.

The Vema Channel, which is the principal pathway by which Antarctic Bottom Water enters the Brazil Basin from the south, is a prime target for paleoceanographic coring and drilling objectives. The topographic constraints of the channel margin are such that the flow is nearly unidirectional at a given location, and currents are sufficiently strong to leave a significant imprint upon the geologic record.

A number of geologic indices have been tested and determined to be potentially reliable indices of paleocirculation in the southwestern Atlantic. Some of these indices appear to reflect water properties in situ, some represent the local direction and/or intensity of advection of near-bottom water, and some are indicative of a mean direction of advection from a distant source, not necessarily reflected in the local flow field.

In deriving paleoceanographic interpretations, one must avoid using a given type of geologic index to infer water mass characteristics not properly associated with such an index. Indices of in situ water properties (e.g., stable isotopes, microfossil assemblages) should not be used to infer changes in flow intensity, because water properties and the flow field generally do not covary in a predictable fashion at a given location. For example, an intensification of AABW flow in the Vema Channel axis would be reflected as a warming in near-bottom temperature on the east flank of the channel, due to the steepening of the isopycnals and isotherms in the channel axis to the west. Consequently, the use of many geologic indices in a given core sequence is required before one can derive paleoceanographic speculations that take into account the known complexity of modern sediment dynamics.

Critical objectives for paleoceanographic drilling in the Rio Grande Rise and Vema Channel region include the identification of the following:

1) Time of initiation of AABW flow into the Brazil Basin and northwestern Atlantic. Does this correspond with the Eocene/Oligocene boundary (Kennett, 1977)?
2) Time of initial formation of northern sources of bottom water, perhaps due to deepening of GreenlandScotland Ridge in the Paleogene.

3) Major pulses of AABW and NADW during the Neogene and Quaternary.

4) Effects of southern hemisphere and northern hemisphere glaciation upon the production of AAIW, NADW, and AABW. Did the stable isotope shifts in the middle Miocene (Savin et al., 1975) and in the Pliocene (Shackleton and Opdyke, 1977) correspond with major readjustments in the flow patterns of the global abyssal circulation?

5) Effects of critical tectonic "threshold events" upon deep thermohaline flow (e.g., opening of Drake Passage; closure of the Isthmus of Panama; outflow from Mediterranean Sill; deepening of Iceland-Scotland Ridge).

\section{ACKNOWLEDGMENTS}

I thank N. Hogg, J. Reid, and B. Warren for their continuing patience with my questions in attempting to understand deep thermohaline circulation. Support for the preparation of this review article was provided under NSF Grant No. OCE80-25208. I thank K. G. Miller and R. L. Carlson for critically reviewing the manuscript. This article is Contribution No. 5188 of the Woods Hole Oceanographic Institution.

\section{REFERENCES}

Arthur, M. A., 1979. Paleoceanographic events-recognition, resolution, and reconsideration. Rev. Geophys. Space Phys., 17:14741494.

Bainbridge, A. L., 1980. GEOSECS Atlantic Expedition (Vol. 2: Sections and Profiles): Washington (U.S. Govt. Printing Office).

Barker, P. F., and Burrell, J., 1977. The opening of Drake Passage. Mar. Geol., 25:15-34.

Barker, P. F., Dalziel, I. W. D., et al., 1977. Init. Repts. DSDP, 36: Washington (U.S. Govt. Printing Office).

Benson, R. H., 1975. The origin of psychrosphere as recorded in changes of deep-sea ostracode assemblages. Lethaia, 8:69-83.

Berger, W. H., 1978. Sedimentation of deep-sea carbonate: maps and models of variations of fluctuations, J. Foraminiferal Res., 8:286-302.

1979. Impact of deep-sea drilling on paleoceanography. In Talwani, M., Hay, W., and Ryan, W. B. F. (Eds.), Deep Drilling Results in the Atlantic Ocean: Continental Margins and Paleoenvironment. (Maurice Ewing Series, Vol. 3): Washington (American Geophysical Union), pp. 297-314.

Berggren, W. A., and Hollister, C. D., 1974. Paleogeography, paleobiogeography and the history of circulation in the Atlantic Ocean. In Hay, W. W. (Ed.), Studies in Paleo-oceanography. Soc. Econ. Paleontol. Mineral. Spec. Publ. 20:126-186.

Biscaye, P. E., Gardner, W. D., and Hogg, N. G., 1981. Suspended particulate matter in Vema Channel. EOS Trans. Am. Geophys. Union, 62:903.

Boyle, E. A., and Keigwin, L., 1982. Deep circulation of the Atlantic over the last 200,000 years: geochemical evidence. Science, 218: 784-787.

Broecker, W. S., 1979. A revised estimate for the radiocarbon age of North Atlantic Deep Water. J. Geophys. Res., 84:3218-3226.

Broecker, W. S., and Takahashi, T., 1978. The relationship between lysocline depth and in situ carbonate ion concentration. Deep-Sea Res., 25:65-95.

1980. Hydrography of the Central Atlantic-III. The North Atlantic Deep Water complex. Deep-Sea Res., 27A:591-613.

Broecker, W. S., Takahashi, T., and Li, Y. H., 1976. Hydrography of the central Atlantic-I. The two-degree discontinuity. Deep-Sea Res., 23:1083-1104.

Burckle, L. H., and Clarke, D. B., 1981. Displaced Antarctic-source diatoms in the Vema Channel. EOS Trans. Am. Geophys. Union, 62:903. 
Buscaglia, J. L., 1971. On the circulation of the Intermediate Water in the southwestern Atlantic Ocean. J. Mar. Res., 29:245-255.

Carmack, E. C., and Foster, T. D., 1975. On the flow of water out of Weddell Sea. Deep-Sea Res., 22:711-724.

Ciesielski, P. F., Ledbetter, M. T., and Ellwood, B. B., 1982. The development of Antarctic glaciation and the Neogene paleoenvironment of the Maurice Ewing Bank. Mar. Geol., 46:1-51.

Corliss, B., 1981. Deep-sea benthonic foraminiferal turnover near the Eocene/Oligocene boundary. Mar. Micropaleontol., 6:367-384.

1982. Linkage of North Atlantic and Southern Ocean deep-water circulation during glacial intervals. Nature, 298:458-460.

Curry, W. B., and Lohmann, G. P., 1982. Carbon isotopic changes in benthic foraminifera from the western South Atlantic: reconstruction of glacial abyssal circulation patterns. Quat. Res., 18:218-235.

Damuth, J. E., and Hayes, D. E., 1977. Echo character of the East Brazilian continental margin and its relationship to sedimentary processes. Mar. Geol., 24:M73-M95.

Detrick, R. S., Sclater, J. G., and Thiede, J., 1977. The subsidence of aseismic ridges. Earth Planet. Sci. Lett., 34:185-196.

Ellwood, B. B., and Ledbetter, M. T., 1977. Antarctic Bottom Water fluctuations in the Vema Channel: effects of velocity changes on particle alignment and size. Earth Planet. Sci. Lett., 35:189-198.

Ewing, M., and Lonardi, A. G., 1971. Sediment transport and distribution in the Argentine Basin. 5. Sedimentary structure of the Argentine margin basin, and related provinces. Physics and Chemistry of the Earth, 8:125-251.

Flood, R. D., 1980. Deep-sea sedimentary morphology: modelling and interpretation of echo-sounding profiles. Mar. Geol., 38: $77-92$.

Fodor, R. V., Husler, J. W., and Kumar, N., 1977. Petrology of volcanic rocks from an aseismic rise: implications for the origin of the Rio Grande Rise, South Atlantic Ocean. Earth Planet. Sci. Lett., $35: 225-233$.

Foster, T. D., and Carmack, E. C., 1976. Frontal zone mixing and Antarctic Bottom Water formation in the southern Weddell Sea. Deep-Sea Res., 23:302-317.

Foster, T. D., and Middleton, J. H., 1980. Bottom water formation in the western Weddell Sea. Deep-Sea Res., 27A:367-381.

$\mathrm{Fu}, \mathrm{L} ., 1981$. The general circulation and meridional heat transport of the subtropical South Atlantic determined by inverse methods. $J$. Phys. Oceanogr., 11:1171-1193.

Gamboa, L. A. P., and Rabinowitz, P. D., 1981. The Rio Grande Fracture Zone in the western South Atlantic and its tectonic implications. Earth Planet. Sci. Lett., 52:410-418.

Georgi, D. T., 1981. Circulation of bottom waters in the southwestern South Atlantic. Deep-Sea Res., 28A:959-979.

Gordon, A. L., 1971. Oceanography of Antarctic waters. In Reid, J. L. (Ed.), Antarctic Oceanology I (Antarctic Research Series, Vol. 15): Washington (American Geophysical Union), pp. 169-203.

Haq, B. U., 1981. Paleogene paleoceanography. Early Cenozoic oceans revisited. Oceanol. Acta., Proc. 26th Int. Geol. Cong., Geol. Oceans Symp., Paris, 7-17 July 1980:71-82.

Hays, J. D., Imbrie, J., and Shackleton, N. J., 1976. Variations in the earth's orbit: pacemaker of the ice ages. Science, 194: pp. $1121-1132$.

Hogg, N. G., in press. Hydraulic control and flow separation in a multi-layered fluid with applications to the Vema Channel. $J$. Phys. Oceanogr., 13.

Hogg, N. G., Biscaye, P. E., Gardner, W., and Schmitz, W. J., 1982. On the transport and modification of Antarctic Bottom Water in the Vema Channel. J. Mar. Res., 40(suppl.):231-263.

Hollister, C. D., Nowell, A. R. M., and Smith, J. D, 1980. The third annual report of the High Energy Benthic Boundary Layer Experiment. WHOI Tech. Rprt. No. 80-32.

Imbrie, J., and Imbrie, J. Z., 1980. Modeling the climatic response to orbital variations. Science, 207:943-953.

Johnson, D. A., 1982. Abyssal teleconnections: The interactive dynamics of the deep ocean circulation. Palaeogeogr. Palaeoclimatol. Palaeoecol., 38:93-128.

Johnson, D. A., Hogg, N., Biscaye, P., and Gardner, W., 1981. The Vema Channel Project: oceanographic perspective and scientific objectives. EOS Trans. Am. Geophys. Union, 62:902.
Johnson, D. A., Ledbetter, M., and Burckle, L. H., 1977. Vema Channel paleooceanography: Pleistocene dissolution cycles and episodic bottom water flow. Mar. Geol., 23:1-33.

Johnson, D. A., McDowell, S. E., Sullivan, L. G., and Biscaye, P. E., 1976. Abyssal hydrography, nephelometry, currents, and benthic boundary layer structure in the Vema Channel. J. Geophys. Res., 81:5771-5786.

Johnson, D. A., and Peters, C. S., 1979. Sedimentation and erosion on the Rio Grande Rise. J. Geol., 87:371-392.

Jones, G. A., and Robinson, F., 1981. Clay mineralogy of the Rio Grande Rise: a sensitive indicator of abyssal circulation. EOS Trans. Am. Geophys. Union, 62:904.

Keigwin, L. D., 1980. Paleoceanographic change in the Pacific at the Eocene-Oligocene boundary. Nature, 287:722-725.

Kennett, J. P., 1977. Cenozoic evolution of Antarctic glaciation, the circum-Antarctic Ocean, and their impact on global paleoceanography, J. Geophys. Res., 82:3843-3860.

Kennett, J. P., and Shackleton, N. J., 1976. Oxygen isotope evidence for the development of the psychrosphere $38 \mathrm{Myr}$ ago. Nature, 260:513-515.

Kroopnick, P., 1980. The distribution of $\mathrm{C}^{13}$ in the Atlantic Ocean. Earth Planet. Sci. Lett., 49:469-484.

Kumar, N., 1979. Origin of "paired" aseismic ridges: Ceara and Sierra Leone Rises in the equatorial, and the Rio Grande Rise and Walvis Ridge in the South Atlantic. Mar. Geol., 30:175-191.

Kumar, N., and Gamboa, L. A. P., 1979. Evolution of the São Paulo Plateau (southeastern Brazilian margin) and implications for the early history of the South Atlantic. Geol. Soc. Am. Bull., 90: 281-293.

Kumar, N., Gamboa, L. A. P., Schreiber, B. C., and Mascle, J., 1977. Geologic history and origin of São Paulo Plateau (southeastern Brazilian margin), comparison with the Angolan margin, and the early evolution of the northern South Atlantic. In Supko, P. R., Perch-Nielsen, K., et al., Init. Repts. DSDP, 39: Washington (U.S. Govt. Printing Office), 927-945.

Kumar, N., Leyden, R., Carvalho, J., and Francisconi, O., 1979. Sediment Isopachs, Continental Margin of Brazil. Chart Series, Am. Assoc. Pet. Geol., Tulsa, Oklahoma.

Ledbetter, M. T., 1979. Fluctuations of Antarctic Bottom Water velocity in the Vema Channel during the last 160,000 years. Mar. Geol., 33:71-89.

Le Pichon, X., Ewing, M., and Truchan, M., 1971. Sediment transport and distribution in the Argentine Basin. 2. Antarctic bottom current passage into the Brazil Basin. Phys. Chem. Earth, 8:31-48.

Lohmann, G. P., 1978. Abyssal benthonic foraminifera as hydrographic indicators in the western South Atlantic Ocean. J. Foraminiferal Res., 8:6-34.

Ludwig, W. J., Krasheninnikov, V., and Shipboard Scientific Party, 1980. Tertiary and Cretaceous paleoenvironments in the southwest Atlantic Ocean: preliminary results of Deep-Sea Drilling Project Leg 71. Geol. Soc. Am. Bull., 91, Part I:55-664.

McCoy, F. W., and Zimmerman, H. B., 1977. A history of sediment lithofacies in the South Atlantic Ocean. In Supko, P. R., PerchNielsen, K., et al., Init. Repts. DSDP, 39: Washington (U.S. Govt. Printing Office), 1047-1079.

McDowell, S., Kumar, N., Jacobi, R. D., Johnson, D. A., and Bunce, E. T., 1977. Regional setting of Site 357, north flank of Rio Grande Rise. In Supko, P. R., Perch-Nielsen, K., et al., Init. Repts. DSDP, 39: Washington (U.S. Govt. Printing Office), 955-969.

Melguen, M., and Thiede, J., 1974. Facies distribution and dissolution depths of surface sediment components from the Vema Channel and the Rio Grande Rise (southwest Atlantic Ocean). Mar. Geol., 17:341-353.

Metcalf, W. G., 1960. Oceanographic data from CRAWFORD cruise 22 trans-Atlantic sections at equator and $24^{\circ}$ south for the International Geophysical Year. WHOI Tech. Rprt. No. 60-3.

Miller, K. G., and Curry, W. B., 1982. Eocene to Oligocene benthic foraminiferal isotopic record in the Bay of Biscay. Nature, 296: 347-352.

Miller, K. G., Gradstein, F. M., and Berggren, W. A, 1982. Late Cretaceous to early Tertiary agglutinated benthic foraminifera in the Labrador Sea. Micropaleontology, 28:1-30. 
Miller, K. G., and Tucholke, B. E., in press. Development of abyssal circulation south of the Greenland-Scotland Ridge. In Bott, M., Talwani, M., Thiede, J., and Saxov, S. (Eds.), Structure and development of the Greenland-Scotland Ridge: New York (NATO Advanced Research Institute, Plenum Press).

Moody, R., Hayes, D. E., and Connary, S., 1979. Bathymetry of the Continental Margin of Brazil. Chart Series, Am. Assoc. Pet. Geol., Tulsa, Oklahoma.

Morley, J. D., and Hays, J. D., 1979. Cycladophora davisiana: a stratigraphic tool for Pleistocene North Atlantic and interhemispheric correlation. Earth Planet. Sci. Lett., 44:383-389.

Needell, G. J., 1980. The distribution of dissolved silica in the deep western North Atlantic Ocean. Deep-Sea Res. 27A:941-950.

Perch-Nielsen, K., Supko, P. R., et al., 1977. Site 357, In Supko, P. R., Perch-Nielsen, K., et al., Init. Repts. DSDP, 39: Washington (U.S. Govt. Printing Office), 231-327.

Peterson, L. C., and Lohmann, G. P., 1982. Major change in Atlantic deep and bottom waters 700,000 yr. ago: benthonic foraminiferal evidence from the South Atlantic. Quat. Res., 17:26-38.

Rabinowitz, P. D., and La Brecque, J., 1979. The Mesozoic South Atlantic Ocean and evolution of its continental margins. J. Geophys. Res., 84:5973-6002.

Reid, J. L., 1978. On the mid-depth circulation and salinity field in the North Atlantic Ocean. J. Geophys. Res., 83:5063-5067.

1979. On the contribution of the Mediterranean Sea outflow to the Norwegian-Greenland Sea. Deep-Sea Res., 26A: 1199-1223.

Reid, J. L., and Lynn, R. J., 1971. On the influence of the NorwegianGreenland and Weddell Seas upon the bottom waters of the Indian and Pacific oceans. Deep-Sea Res., 18:1063-1088.

Reid, J. L., Nowlin, W. D., and Patzert, W. C., 1977. On the characteristics and circulation of the southwestern Atlantic Ocean. $J$. Phys. Oceanogr., 7:62-91.

Richardson, M. J., Wimbush, M., and Mayer, L., 1981. Exceptionally strong near-bottom flows on the continental rise of Nova Scotia. Science, 213:887-888.

Ruddiman, W. F., McIntyre, A., Niebler-Hunt, V., and Durazzi, J. T., 1980. Oceanic evidence for the mechanism of rapid northern hemisphere glaciation. Quat. Res., 13:33-64.

Ryan, W. B. F., 1976. Quantitative evaluation of the depth of the western Mediterranean before, during and after the late Miocene salinity crisis. Sedimentology, 23:791-813.

Ryan, W. B. F., Cita, M. B., Rawson, M. D., Burckle, H. H., and Saito, T., 1974. A paleomagnetic assignment of Neogene state boundaries and the development of isochronous datum planes between the Mediterranean, the Pacific and Indian oceans in order to investigate the response of the world ocean to the Mediterranean "salinity crisis". Riv. Ital. Paleontol. 80:631-688.

Sarmiento, J. L., Broecker, W. S., and Biscaye, P. E., 1978. Excess bottom radon 222 distribution in deep ocean passages. $J$. Geophys. Res., 83:5068-5076.

Savin, S. M., Douglas, R. G., and Stehli, F. G., 1975. Tertiary marine paleotemperatures. Geol. Soc. Am. Bull., 86:1449-1510.

Schlanger, S. O., Jenkyns, H. C., and Premoli-Silva, I., 1981. Volcanism and vertical tectonics in the Pacific Basin related to global Cretaceous transgressions. Earth Planet. Sci. Lett., 52:435-449.
Schnitker, D., 1980a. North Atlantic oceanography as possible cause of Antarctic glaciation and eutrophication. Nature, 284:615-616. 1980b. Global paleoceanography and its deep water linkage to the Antarctic glaciation. Earth Sci. Rev., 16:1-20.

Sclater, J. G., and McKenzie, D. P., 1973. Paleobathymetry of the South Atlantic. Geol. Soc. Am. Bull., 84:3203-3216.

Sclater, J. G., Hellinger, S., and Tapscott, C., 1977. The paleobathymetry of the Atlantic Ocean from the Jurassic to the Present. $J$. Geol., 85:509-552.

Seabrooke, J. M., Hufford, G. L., and Elder, R. B., 1971. Formation of Antarctic Bottom Water in the Weddell Sea. J. Geophys. Res., 76:2164-2177.

Shackleton, N. J., and Opdyke, N. D., 1977. Oxygen isotope and palaeomagnetic evidence for early Northern Hemisphere glaciation. Nature, 270:216-219.

Streeter, S. S., and Shackleton, N. J., 1979. Paleocirculation of the deep North Atlantic: 150,000-year record of benthic foraminifera and oxygen-18. Science, 203:168-171.

Thiede, J., 1977. Subsidence of aseismic ridges: evidence from sediments on Rio Grande Rise (southwest Atlantic Ocean). Am. Assoc. Pet. Geol. Bull., 61:929-940.

Thunell, R. C., 1981a. Late Miocene-Early Pliocene planktonic foraminiferal biostratigraphy and paleoceanography of low-latitude marine sequences. Mar. Micropaleontol., 6:71-90.

1981b. Calcite and aragonite dissolution trends in surface sediments from the Vema Channel. EOS Trans. Am. Geophys. Union, 62:903.

Warren, B. A., 1981. The deep circulation of the world's oceans, In Warren, B., and Wunsch, C. (Eds.), Evolution of Physical Oceanography: Scientific Surveys in Honor of Henry Stommel: Cambridge, MA (MIT Press), pp. 6-41.

Whitehead, J. A., and Worthington, L. V., 1982. The flux and mixing rates of Antarctic Bottom Water within the North Atlantic. $J$. Geophys. Res., 87:7903-7924.

Williams, D. F., and Ledbetter, M. T., 1979. Chronology of Late Brunhes biostratigraphy and Late Cenozoic disconformities in the Vema Channel (South Atlantic). Mar. Micropaleontol., 4:125-136.

Worthington, L. V., 1976. On the North Atlantic Circulation. Johns Hopkins Oceanographic Studies, Vol. 6.

Wright, W. R., 1969. Deep water movement in the western Atlantic as determined by use of a box model. Deep-Sea Res., 16 (Suppl): 433-466.

Wunsch, C., 1978. The general circulation of the North Atlantic west of $50^{\circ} \mathrm{W}$ determined from inverse methods. Rev. Geophys. Space Phys., 16:583-620.

Wuist, G., 1936. Schichtung und Zirkulation des Atlantischen Ozeans, In Defant, A. (Ed.), Wissenschaftliche Ergebnisse deutschen Atlantischen Expedition Meteor, 1925-1927 (Vol. 6): Berlin, Leipzig (Walter de Gruyter and Co.), 108-288.

Wyrtki, K., 1973. Teleconnections in the equatorial Pacific Ocean. Science 180:66-68.

Date of Initial Receipt: June 11, 1982 